\title{
Da Hegemonia Sanitarista ao Predomínio Liberal: Investigando os Fatores que Impediram uma Inflexão Liberal na Agência Nacional de Saúde Suplementar (ANS) (2004-2014)
}

\author{
Marcello Fragano Baird \\ Doutor em Ciência Política pela Universidade de São Paulo (USP). Professor do curso de Relações \\ Internacionais na Escola Superior de Propaganda e Marketing (ESPM). Professor no MBA em Economia e \\ Gestão - Relações Governamentais da FGV-SP. \\ E-mail: marcellofb@hotmail.com, https://orcid.org/0000-0001-7675-7577
}

\section{INTRODUÇÃO}

$\mathrm{O}$ setor de planos de saúde no Brasil gera bilhões de reais de faturamento e envolve empresas poderosas, como a Amil, a Bradesco Saúde e a Qualicorp. Grupos sanitaristas, defensores do sistema público de saúde, e entidades de defesa dos consumidores, proponentes de uma regulação mais abrangente, também se mobilizam dentro do setor. O principal lócus de embate dessas forças é a Agência Nacional de Saúde Suplementar (ANS), responsável por regular o setor.

O objetivo deste artigo é analisar a política do setor de saúde suplementar, com foco na disputa de poder na ANS. Para cumprir essa tarefa, realizamos uma análise do jogo político na agência entre 2004 e 2014, caracterizando o embate de forças políticas dentro da agência a partir das nomeações políticas aos cargos de direção. Ao mapear as redes de relações e a trajetória dos diretores, identificamos os grupos políticos com suas agendas que atuaram na ANS ao longo de quatro gestões.

Paralelamente, examinamos as decisões-chave tomadas pela ANS, de forma a observar os direcionamentos regulatórios mais gerais produzidos em cada gestão. Ao cotejar a coalizão dominante com as regulações editadas pela agência, pudemos verificar o exercício da 
influência na ANS e, no limite, quais projetos políticos foram implementados com maior êxito.

A literatura sobre regulação, muito formalista e ancorada em alguns enfoques analíticos, como captura e relação agente-principal, não tem dado conta de abarcar a complexidade do jogo político na regulação estatal. O presente artigo, aliando fatores institucionais, políticos e setoriais, como o papel da burocracia da ANS, o arcabouço regulatório do setor e o próprio formato organizacional das empresas que atuam nesse mercado, pretende contribuir para os estudos sobre política, políticas públicas, burocracia, grupos de interesse e o próprio funcionamento do Estado brasileiro.

Na próxima seção, discutiremos a literatura sobre regulação. Em seguida, trataremos do setor de saúde suplementar e do desenho institucional da ANS. A seção seguinte será dedicada à caracterização dos embates políticos na ANS e à influência daí resultante na regulação. Na sequência serão discutidos os fatores políticos, institucionais e setoriais que explicam a influência e a conformação mais geral do setor. Ao final, resumiremos algumas conclusões e traçaremos um panorama do setor.

\section{ELEMENTOS PARA UMA ANÁLISE DA CONFIGURAÇÃO POLÍTICO- INSTITUCIONAL-SETORIAL}

A literatura que trata de regulação teve diversos desenvolvimentos, mas nenhum parece ter conseguido construir um arcabouço teórico sofisticado o bastante para dar conta das complexas relações existentes entre sistema político, burocracia e grupos de interesse. A seguir passamos em revista pelas diversas teorias para avaliar seus limites e aportes para a compreensão do fenômeno regulatório.

O primeiro corpo teórico a se ocupar de questões regulatórias foi a teoria do interesse público, em voga nos Estados Unidos nas décadas de 1950 e 1960. De cunho fortemente normativo, essa teoria simplesmente buscava justificar a necessidade de regulação estatal a partir das falhas de mercado, com vistas a garantir a maximização do bem-estar da população (Majone, 1999).

No início da década de 1970, uma nova corrente teórica surgiu contrariando os postulados da teoria anterior e revelando uma outra fa- 
ceta da regulação: a captura. A teoria da regulação econômica ou da captura alertava para o fato de que a regulação costumava ser posta em marcha não para corrigir falhas de mercado, mas para beneficiar indústrias em detrimento dos consumidores. Desenvolvida na Escola de Chicago com base em modelagem econômica e na assunção da maximização de interesses, essa abordagem propunha que as indústrias demandariam regulação para se proteger da concorrência, enquanto os políticos ofertariam essa regulação, pois dependeriam dos recursos do setor privado para se financiar e sobreviver politicamente (Stigler, 1975).

Essas teorias foram alvo de inúmeras críticas por seu caráter formalista e, principalmente, pelo papel marginal atribuído às variáveis político-institucionais. Moe foi certeiro e incisivo ao criticar a teoria da captura, igualando-a ao pluralismo:

Conhecida como teoria da captura, trata-se, em realidade, de uma versão formal do pluralismo, na qual políticas públicas são compreendidas a partir dos interesses sociais e os recursos que podem mobilizar. As instituições são propositalmente omitidas desses modelos, aparecendo como caixas pretas que misteriosamente fazem a mediação entre interesses sociais e os resultados políticos. (Moe, 1987:475, tradução livre)

A teoria positiva das instituições, cuja perspectiva teórica é a relação agente-principal, foi a principal resposta da Ciência Política à ausência de instituições nas discussões vigentes. $\mathrm{O}$ foco dessa corrente, que também parte de pressupostos economicistas, como assimetria de informações, está no controle político. Como as políticas públicas só podem funcionar mediante delegação, objetiva-se analisar como os atores políticos lançam mão de mecanismos para controlar o funcionamento das agências. Essa teoria surgiu analisando os meios pelos quais o Congresso norte-americano buscava monitorar as agências; posteriormente, o escopo analítico foi expandido para se compreender a supervisão exercida pelo Executivo e pelo Judiciário (Carrigan e Coglianese, 2011).

Embora essas novas correntes teóricas, especialmente a perspectiva do agente-principal, levem em conta elementos institucionais, algumas questões não são tratadas com a devida profundidade e outras sequer são abordadas, como as relações entre Executivo e Legislativo, o papel do profissionalismo burocrático e o contexto político. Novamente Moe 
(1985), agora num artigo sobre o órgão regulador das relações trabalhistas nos EUA, é quem defende que a teoria positiva das instituições funcione como uma perspectiva ampliada do agente-principal:

Nesse sentido, é possível analisar simultaneamente a influência do presidente e das comissões no Congresso, o papel moderador do Judiciário, o impacto das condições econômicas, as decisões internas dos burocratas governamentais e o comportamento ressentido entre patrões e empregados - e fazer essa análise levando em conta o contexto e a interdependência entre essas partes no sistema regulatório em que estão inseridos. (Moe, 1985:1095, tradução livre)

Nesse sentido, este estudo pretende contribuir com elementos para que análises mais sofisticadas e realistas de como interagem atores sociais e político-institucionais na produção de políticas públicas ou de regulações estatais possam ser feitas. Isso significa, seguindo a recomendação de Moe (1985), ampliar a perspectiva agente-principal para incluir outras questões além do controle político, como a interação com Executivo e Legislativo, o papel da autonomia burocrática e as características do setor.

O ponto de partida, necessariamente, para se analisar o direcionamento mais geral e os resultados regulatórios de uma burocracia pública federal, como a ANS, é atentar para o sistema de governo, especialmente a relação entre os Poderes Executivo e Legislativo. O funcionamento do presidencialismo de coalizão brasileiro tem como base o compartilhamento do poder por meio da construção de uma coalizão de governo (Limongi e Figueiredo, 2001). Isso significa, na prática, que o presidente da República precisa distribuir cargos para obter apoio político no Congresso Nacional (Praça, Freitas e Hoepers, 2011). No caso das agências reguladoras, o poder de barganha do Legislativo e, particularmente, do Senado Federal, torna-se maior, na medida em que as indicações presidenciais devem passar por sabatina e aprovação naquela Casa.

É sob essa lógica de funcionamento das relações entre Executivo e Legislativo que analisaremos as indicações aos postos de comando da ANS. As nomeações devem ser compreendidas como a possibilidade de alçar ao poder uma determinada agenda política. Daí a importância de, como faremos neste trabalho, evidenciar as redes de relações, dentro e fora do governo, que dão sustentação ao indicado para ocupar um posto na diretoria colegiada da agência. Assim, cada nome- 
ado será visto como portador de um projeto político de determinada coalizão de interesses.

Entendemos que o esforço empírico de inserir as agências no contexto do complexo político-burocrático brasileiro e atentar para o significado político das nomeações ganha ainda mais importância ao se ter em mente que um dos principais corpos teóricos sobre as agências reguladoras é a nova economia institucional, focada na construção de um modelo autônomo para esses órgãos como forma de garantir a credibilidade e minar ações oportunistas do governo (Levy e Spiller, 1996). Como demonstraremos, a maior autonomia formal conferida às agências reguladoras, incluindo o mandato fixo dos dirigentes, não a exclui da disputa de poder dentro e fora do governo, o que acaba por se materializar justamente pela nomeação de seu corpo dirigente, assim como em qualquer outro órgão.

Ainda em relação à literatura sobre agências reguladoras, vale destacar que, no Brasil, os principais estudos têm enquadramento mais formal, não buscando compreender como os mais diversos interesses são transplantados e gerenciados no interior das mesmas. Alguns trabalhos, ancorados na abordagem do agente-principal, como o de Silva (2010), procuram mensurar a independência desses órgãos. Outros, como o de Bonis (2016), esmiúçam o perfil das nomeações, levando em consideração trajetória profissional e filiação partidária. Nosso trabalho também parte dos atributos, bem como das conexões políticas, mas dá um passo adiante no sentido de compreender os projetos e ideias em disputa nas nomeações e, principalmente, como essas agendas se traduzem em normas regulatórias.

Retomando a discussão sobre outros elementos fundamentais para a compreensão da produção regulatória, os quais são, via de regra, ignorados pela literatura do agente-principal, é importante destacar, para além da relação Executivo-Legislativo, dois fatores relevantes. Em primeiro lugar, o papel da profissionalização e autonomia burocráticas. Os trabalhos norte-americanos sobre burocracia costumam levar em conta o papel central da autonomia das diversas agências governamentais, especialmente quando há conflito entre os Poderes Executivo e Legislativo, o que costuma gerar maior espaço discricionário para os burocratas (Wilson, 1989). 
A profissionalização e estabilidade típicas do modelo weberiano também contribuem para o fortalecimento e a autonomia de organizações burocráticas, que passam a ter interesses e visões de mundo próprias. Esse processo tende a reduzir o peso das indicações políticas, pois os indivíduos que assumem os cargos de direção se veem divididos entre a lealdade aos políticos que o nomearam e ao corpo burocrático e projetos da organização que devem liderar. Quem menciona isso de forma jocosa é Wilson, segundo o qual, imediatamente após fazer o juramento para assumir um cargo de direção burocrática,

[...] aqueles que fizeram o juramento começam a experimentar uma conversão que transforma o espírito. De repente eles começam a ver o mundo pelas lentes dos órgãos onde trabalham - as necessidades não atendidas, as pautas não levadas adiante, os funcionários leais e trabalhadores (Wilson, 1989:260, tradução livre).

O outro elemento que deve ser acrescentado numa análise holística de uma regulação estatal é o contexto ou a configuração do setor. Quem introduziu essa ideia de forma pioneira foi Lowi, ao inverter a lógica tradicional da Ciência Política e afirmar que não apenas a política impacta as políticas públicas, mas que as políticas públicas também afetam a política, de tal modo que "[...] Não se pode dizer muitas novidades sobre a política da regulação sem introduzir o contexto geral da política pública no qual a regulação é apenas uma pequena, embora importante, parte" (Lowi, 1972:299, tradução livre). Isso significa atentar para o contexto da regulação na saúde suplementar e dos atores nela inseridos, de modo a verificar como esses elementos impactam os processos políticos e a configuração do setor.

Mesmo sem a pretensão de construir um modelo analítico completo, entendemos que somente a conjugação de fatores políticos, institucionais e setoriais terá o condão de explicar a política e a influência no âmbito da ANS.

\section{O SETOR DE SAÚDE SUPLEMENTAR E A ANS}

O Brasil é hoje o segundo maior mercado de planos privados de saúde do mundo, atrás apenas dos EUA. Aproximadamente 47 milhões de pessoas, o equivalente a $25 \%$ da população, têm planos de saúde. Para que se tenha uma ideia da força do setor, basta observar que 
as mais de 1.000 empresas que nele atuam tiveram uma receita de mais de R\$ 179 bilhões em 2017, valor bastante superior ao orçamento aprovado para o Sistema Único de Saúde (SUS) no ano passado, de R $\$ 125$ bilhões, responsável por atender os outros três quartos da população (ANS, 2018).

Empresas atuavam no setor sem qualquer regulação desde 1940. Em que pese a criação do SUS em 1988, a saúde suplementar passou por forte expansão durante as décadas de 1980 e 1990. Com isso, cresceu a mobilização pela regulamentação da saúde privada. Foi assim que, em 1998, pela primeira vez, a saúde suplementar foi regulada.

A Lei $n^{\circ} 9.656 / 98$, que regula o setor, tem dois eixos centrais: a regulação econômica e a assistencial. Do ponto de vista econômico-financeiro, estabeleceram-se requisitos para o funcionamento das operadoras de planos de saúde, como demonstração de capacidade de atendimento e de viabilidade econômico-financeira e obrigatoriedade de manutenção de provisões técnicas. No eixo assistencial, verificou-se importante avanço, na medida em que regras de proteção ao consumidor foram estabelecidas. Em primeiro lugar, destaca-se a instituição do plano-referência de assistência à saúde, por meio do qual as operadoras ficaram impedidas de comercializar planos que restrinjam a quantidade de procedimentos realizados e excluam a cobertura a doenças em desacordo com a regulação da ANS - a cada dois anos a agência atualiza esse rol de procedimentos cobertos. Essa foi a principal resposta da legislação àquilo que era comumente denominado de "Plano Melhoral", que só oferecia algumas consultas e tratamentos. Outras medidas importantes foram o teto de reajuste estabelecido anualmente pela agência e a proibição do rompimento unilateral de contratos, ambos em planos individuais. Definiu-se também a garantia de ressarcimento ao SUS caso o cliente de um plano privado utilize a rede pública.

A ANS seria criada apenas em 2000, reunindo na agência a regulação das funções acima arroladas com o objetivo de "promover o interesse público na assistência suplementar à saúde, regulando as operadoras setoriais" (Brasil, 1998). A ANS é uma autarquia especial vinculada ao Ministério da Saúde e, como as demais agências reguladoras federais, tem autonomia financeira, administrativa e política, na medida em que seus dirigentes têm mandato fixo de três anos (com direito a uma recondução) e não podem ser demitidos ad nutum pelo presi- 
dente da República. Isso ocorre apesar de os diretores serem indicados pelo presidente e aprovados pelo Senado.

A ANS possui uma diretoria colegiada composta por cinco diretores, sendo um deles nomeado, via decreto, pelo presidente, para assumir o cargo de diretor-presidente. A diretoria mais poderosa é a Diretoria de Normas e Habilitação de Produtos (Dipro), responsável pela regulação assistencial (rol de procedimentos e teto de reajuste), seguida pela Diretoria de Normas e Habilitação de Operadoras (Diope), responsável pelas regras econômico-financeiras das empresas. Desde a $2^{\mathrm{a}}$ gestão, o diretor da Dipro assume também a presidência da agência.

À Diretoria de Desenvolvimento Setorial (Dides) compete garantir o ressarcimento das empresas ao SUS. As outras duas diretorias são a de Fiscalização (Difis) e de Gestão (Diges). A primeira tem a função de apurar e aplicar sanções às empresas; a segunda deve coordenar as questões administrativas, financeiras e de pessoal.

\section{METODOLOGIA}

O ponto central de nossa análise é caracterizar o jogo político e a intermediação de interesses na ANS. Essa discussão envolverá a reconstituição dos principais grupos políticos na agência e a análise das grandes linhas de ação e/ou decisões-chave tomadas pela ANS nas diferentes gestões entre 2004 e 2014 ${ }^{1}$. A melhor forma de atingir esse resultado é combinar a análise das conexões existentes entre os diretores da agência e os atores políticos da coalizão governamental com a observação da trajetória profissional e do perfil dos diretores indicados em cada gestão.

Afastamo-nos, assim, em alguma medida, dos estudos de lobby, como o de Baird (2016), mais focados nas ações pontuais dos grupos de interesse. Adotamos aqui uma abordagem de cunho mais estrutural, capaz de identificar a inserção dos atores, com suas agendas e projetos, e, por conseguinte, a estrutura e distribuição de poder existentes no âmbito da ANS, analisando como isso se traduziu, ao longo do tempo, em resultados políticos concretos. Ao fazê-lo, teremos condições de avaliar a influência exercida e também se há sinais de captura da ANS, com o favorecimento do mercado em detrimento dos consumidores, conforme enunciam autores como Scheffer e Bahia (2010). 
Para a reconstituição do jogo político, fizemos uso de métodos mistos. Por um lado, recorremos à pesquisa documental e ao trabalho de campo com a realização de entrevistas semiestruturadas. Ao todo, foram realizadas 45 entrevistas com a elite do setor: empresários, diretores e funcionários da ANS e ex-ministros da Saúde. Por outro lado, das entrevistas realizadas, 28 tiveram uma segunda parte dedicada à coleta de dados para a montagem das redes.

Para a análise de redes, seguimos o procedimento de Marques (2003), cuja premissa é identificar algumas lideranças do setor e deixar que as próprias pessoas que atuam na área estabeleçam as conexões existentes. Assim, criamos inicialmente uma "semente", uma lista com 31 figuras-chave do setor ao longo da história da ANS. Líamos para os entrevistados um a um os nomes da lista. Nesse processo, pedíamos que os entrevistados apontassem até três nomes que estivessem associados a cada um dos nomes da lista. Assim, as conexões entre as pessoas no setor foram se revelando. Pedimos também aos informantes que identificassem o período de início dessas relações. Ao final da pesquisa, a rede tinha 204 pessoas conectadas por meio de 849 relações. No entanto, para dar maior confiabilidade à pesquisa, optamos por excluir as relações mencionadas apenas uma vez, restando 146 pessoas conectadas por meio de 414 relações. Essas informações foram então transportadas para o software Ucinet (Borgatti, Everett e Freeman, 2002), responsável pela produção de estatísticas referentes às redes elaboradas. Este software também contém uma ferramenta de visualização chamada NetDraw, que produziu as figuras das redes apresentadas na pesquisa, chamadas de sociogramas.

Assim, pudemos montar as redes divididas em quatro períodos correspondentes às gestões dos diretores-presidentes da ANS entre 2004 e 2014. Para poder caracterizar as pessoas das redes por meio de atributos, como pertencimento ao setor público e a campos político-ideológicos, lançamos mão não apenas das entrevistas, mas também analisamos o currículo dos 146 indivíduos da rede ao longo dos quatro períodos, em bases como o Linkedin e o Currículo Lattes.

Essas informações nos permitiram caracterizar o principal embate dentro da ANS, qual seja, entre as visões liberal e sanitarista. Os sanitaristas são historicamente ligados à construção do SUS e refratários ao crescimento do setor privado de maneira geral. Não à toa, sua participação na regulamentação da saúde suplementar foi residual. Uma 
vez na ANS, tiveram que lidar com esse setor em funcionamento. De maneira geral, seus objetivos voltaram-se para a intensificação da regulação assistencial, ou seja, para a expansão da proteção ao consumidor. Os liberais, por sua vez, seja por ideologia, seja por trajetória vinculada ao mercado, defendiam uma abordagem menos intervencionista e favorável à expansão do mercado, visando flexibilizar a regulação existente e impedir a imposição de novos ônus ao setor ${ }^{2}$.

As informações referentes às grandes linhas de ação das diferentes gestões da ANS foram obtidas por meio de três instrumentos. Inicialmente, analisamos as principais resoluções expedidas pela agência entre 2004 e 2014, que representam as políticas mais amplas adotadas pela ANS. Fizemos um recorte no tipo de decisão a ser analisada. Assim, da miríade de tipos normativos existentes na agência (Instrução Normativa, Súmula, etc.), interessava-nos observar as decisões que efetivamente importavam impacto regulatório no setor. Nesse sentido, seguindo modelo adotado por Matos (2011), restringimo-nos à análise das Resoluções Normativas (RN). Em função da tecnicidade das normas e com vistas a garantir uma análise mais abrangente, complementamos essas informações com a análise dos relatórios de gestão da agência e com o suporte narrativo de entrevistados.

\section{REDES DE INFLUÊNCIA E JOGO POLÍTICO NA ANS}

Períodos 2004-2006 e 2007-2009: as gestões sanitaristas do Partido dos Trabalhadores (PT)

O período da primeira gestão da ANS (2000-2003), único sob o comando do PSDB, foi marcado pela grande força política do ministro da Saúde, José Serra, que teve grande liberdade para compor a diretoria colegiada sem ter de negociar cargos com outros partidos da coalizão. O segundo e o terceiro períodos correspondem aos anos de 2004 a 2006 e 2007 a 2009, momento em que o PT já havia sucedido o PSDB no governo federal. Como essas duas gestões apresentam forte linha de continuidade, optamos por agrupá-las na mesma seção. O período petista traz um cenário de maior compartilhamento de poder com a coalizão governante e disputas dentro do próprio partido. Essa multiplicidade de atores pode ser observada na figura abaixo, que traz as relações existentes entre os diretores da ANS, os ministros da Saúde e os políticos ${ }^{3}$. A espessura dos laços entre os atores indica a intensidade dessa relação, medida pelo número de citações. 
Figura 1

Rede entre diretoria colegiada da ANS, políticos e ministro da Saúde (2004-2006)

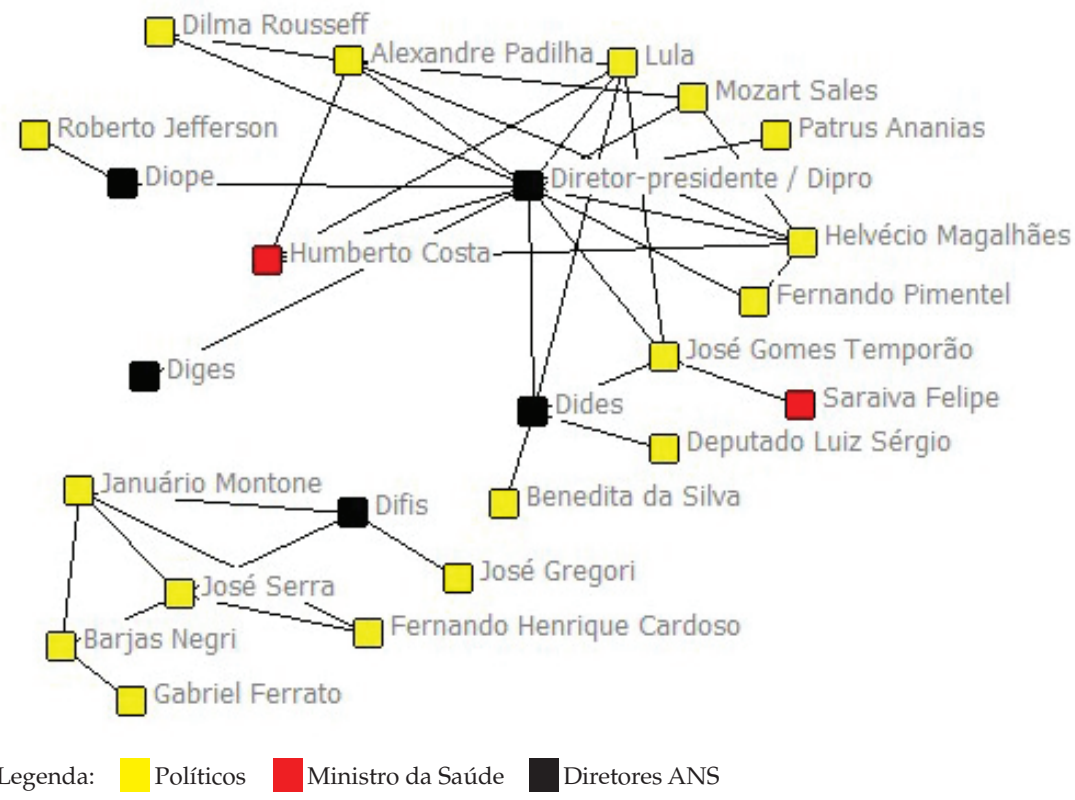

Fonte: Elaboração própria a partir de entrevistas feitas pelo autor.

Com a passagem de poder do PSDB para o PT, a quase totalidade dos diretores foi trocada. A única remanescente foi Maria Stella Gregori, da Difis, que teve seu mandato renovado antes do término do governo Fernando Henrique Cardoso. É possível notar que ela permaneceu isolada no governo do PT. Os políticos do período anterior aparecem vinculados a Gregori, mas sem ligações com a nova diretoria. Assim, pode-se considerar que esse grupo teve seu último momento de influência na agência.

O governo comandou a montagem da diretoria colegiada nas quatro vagas remanescentes. O PT dividiu entre si a ocupação de três diretorias, negociando a última com outro partido da base aliada, o Partido Trabalhista Brasileiro (PTB). O ministro Humberto Costa indicou Fausto dos Santos, médico sanitarista de Minas Gerais, à Dipro e à presidência da agência, contemplando o PT-MG. Fausto indicou pessoalmente Gilson Caleman, um sanitarista histórico, para a comandar a Diges. O caráter pessoal da escolha fica evidenciado pela Diges não apresentar nenhuma outra relação na rede. 
Dois grupos distintos do PT, em realidade, disputaram as vagas da agência. Além do PT-MG, o PT-RJ mostrou-se muito influente na ANS, emplacando José Leôncio Feitosa na Dides. Além de médico pessoal do ex-presidente Lula, Feitosa havia sido secretário de Saúde de Benedita da Silva, ex-governadora do Rio de Janeiro até o final de 2002.

Por fim, há o indicado, pela primeira vez, de um partido da coalizão, o PTB. O deputado federal Roberto Jefferson (PTB-RJ) indicou Alfredo Cardoso, vinculado à Amil, para assumir a Diope. O apoio de Jefferson expressa, na verdade, a força da Amil. Segundo relatos, Edson Bueno, dono da Amil, teria feito algumas indicações, via aliados, e o nome de Alfredo Cardoso foi o que vingou (entrevista ao autor). Desde então, a Amil passou a contar com um diretor com passagem em seus quadros na Diope, indicado, inclusive, por partidos diferentes. Isso denota que a empresa tem um papel mais relevante do que eventuais partidos aliados na conformação da diretoria colegiada da ANS. O quadro a seguir traz a composição completa da diretoria colegiada.

Quadro 1

Perfil diretoria colegiada ANS (2004-2006)

\begin{tabular}{llccl}
\hline Nome & Posição/Cargo & Governo & Partido & Instituição anterior \\
\hline $\begin{array}{l}\text { Fausto Pereira } \\
\text { dos Santos }\end{array}$ & $\begin{array}{l}\text { Diretor-presi- } \\
\text { dente / Dipro }\end{array}$ & Lula 1 & PT & Ministério da Saúde \\
$\begin{array}{llcl}\text { Gilson Caleman } \\
\text { Diretor Diges }\end{array}$ & Lula 1 & & $\begin{array}{l}\text { Faculdade de Me- } \\
\text { dicina de Marília }\end{array}$ \\
$\begin{array}{l}\text { Gregori } \\
\text { Alfredo Cardoso }\end{array}$ & Diretor Difis & Lula 1 & Procon/SP \\
José Leôncio & Diretor Dides & Lula 1 & Amil \\
Feitosa & Lula 1 & PT & $\begin{array}{l}\text { Secretaria de Estado } \\
\text { de Saúde/RJ }\end{array}$ \\
\hline
\end{tabular}

Fonte: Elaboração própria a partir de entrevistas feitas pelo autor.

O fato mais relevante a se identificar é que, a partir desse período, a disputa central na ANS passa a ser entre liberais, favoráveis à expansão do mercado, e sanitaristas, que propugnam uma regulação mais rígida e abrangente. Os grupos sanitaristas ligados ao PT são majoritários nesse período, ocupando a presidência da agência junto com a Dipro, a Dides e a Diges, enquanto os liberais aparecem representados apenas na Diope. 
A Difis, cuja diretora era oriunda e ligada a entidades de defesa do consumidor, não apresentava nenhum alinhamento automático.

O período seguinte não apresenta grande variação, até pela renovação de três diretores. Destaque-se que, embora Roberto Jefferson permaneça vinculado a Cardoso, da Diope, o deputado já perdera seu mandato no "Mensalão". O senador Renan Calheiros (Partido do Movimento Democrático Brasileiro - PMDB-AL) teve papel central na recondução de Cardoso (entrevista ao autor). Esse fato é o primeiro indício na ANS da crescente e intensa ligação entre PMDB e Amil.

As duas mudanças na composição da diretoria colegiada ocorreram na Difis, com a saída de Gregori, e na Diges, com a saída de Caleman. A Difis foi ocupada por Eduardo Sales, procurador federal vinculado ao PT do Rio de Janeiro e, particularmente, ao deputado federal Luiz Sérgio (PT-RJ). Assim, o PT-RJ, que já dirigia a Dides, foi fortalecido com a Difis. Hésio Cordeiro, filiado ao Partido Democrático Trabalhista (PDT), foi indicado para a Diges pelo ministro da Saúde, José Temporão, do PMDB. A figura a seguir traz essas mudanças.

Figura 2

Rede entre diretoria colegiada da ANS, políticos e ministro da Saúde (2007-2009)

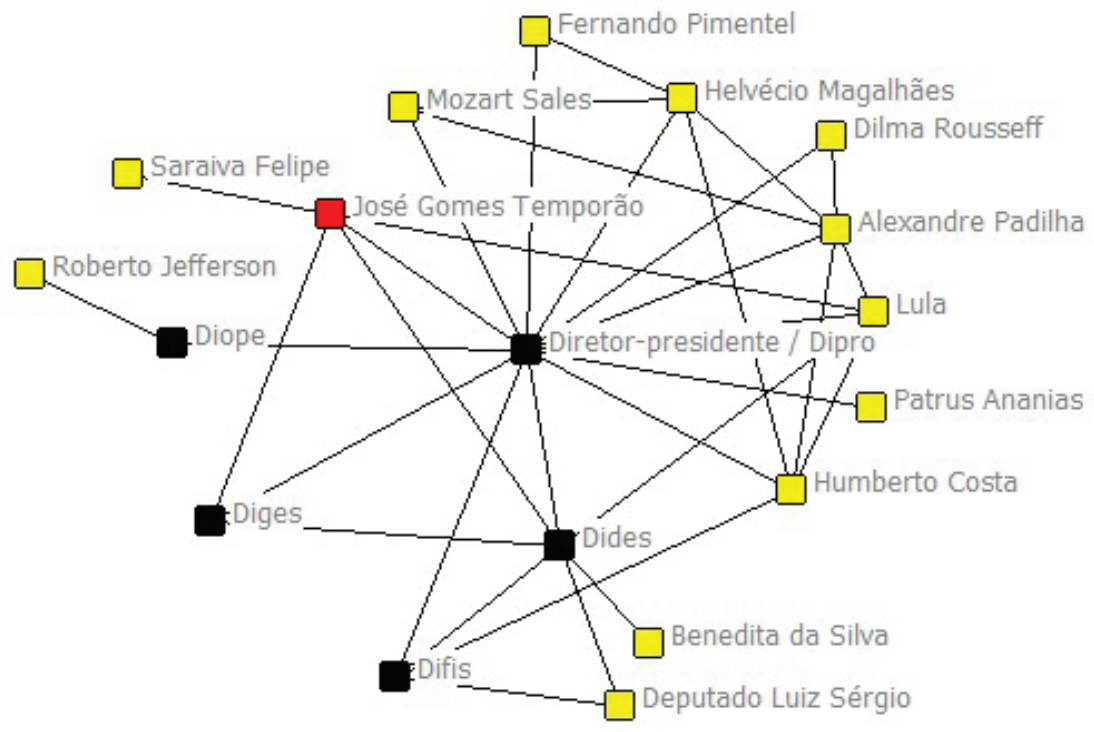

Legenda: Políticos Ministro da Saúde Diretores ANS

Fonte: Elaboração própria a partir de entrevistas feitas pelo autor.

DADOS, Rio de Janeiro, vol.62(4):e20180295, 2019. 
A segunda gestão petista na ANS teve uma linha de continuidade em relação à primeira, com a permanência da disputa entre sanitaristas e liberais. A saída de Caleman não alterou esse quadro, pois seu substituto, Cordeiro, também era sanitarista e se alinhava com esse grupo. Com a indicação de Sales, outro quadro ligado ao PT, reforçava-se ainda mais o grupo sanitarista, em oposição à Diope. Embora viesse da carreira jurídica, Sales compunha com os sanitaristas, comandados por Fausto. Em realidade, o lado sanitarista foi fortalecido, pois, no limite, a principal mudança nesse período foi a substituição de uma diretora consumerista por um diretor da área jurídica, mas alinhado partidária ${ }^{4}$ e politicamente à ala sanitarista. $\mathrm{O}$ quadro abaixo resume essa composição.

Quadro 2

Perfil diretoria colegiada ANS (2007-2009)

\begin{tabular}{lllll}
\hline Nome & Posição/Cargo & Governo & Partido & Instituição anterior \\
\hline $\begin{array}{l}\text { Fausto Pereira } \\
\text { dos Santos }\end{array}$ & $\begin{array}{l}\text { Diretor-presidente } \\
\text { / Dipro }\end{array}$ & Lula 2 & PT & Ministério da Saúde \\
$\begin{array}{l}\text { Alfredo } \\
\text { Cardoso }\end{array}$ & Diretor Diope & Lula 2 & & Amil \\
$\begin{array}{l}\text { José Leôncio } \\
\text { Feitosa }\end{array}$ & Diretor Dides & Lula 2 & PT & $\begin{array}{l}\text { Secretaria de Estado de } \\
\text { Saúde/RJ }\end{array}$ \\
Hésio Cordeiro & Diretor Diges & Lula 2 & PDT & $\begin{array}{l}\text { Universidade Estácio } \\
\text { de Sá }\end{array}$ \\
& & & & $\begin{array}{l}\text { Advocacia-Geral da } \\
\text { União }\end{array}$ \\
\hline
\end{tabular}

Fonte: Elaboração própria a partir de entrevistas feitas pelo autor.

Nesse contexto, seria de se esperar que o predomínio da vertente sanitarista gerasse regulações mais pró-consumidor, enquanto caberia à Diope veicular posições do empresariado. Segundo interlocutores na agência, Cardoso buscou, por várias vezes, transferir a atribuição de controle do reajuste de preços da Dipro para a Diope. Mesmo sem sucesso na empreitada, ele defendia tetos de reajuste maiores do que aqueles propostos pela Dipro (entrevista ao autor).

Em relação ao posicionamento mais geral da Diope, diversos entrevistados afirmaram que a diretoria tinha forte orientação pró-grandes empresas, de modo que o principal enfrentamento interno na agência 
era em torno de não regular tão fortemente o setor do ponto de vista econômico, de maneira a inviabilizar as pequenas operadoras (entrevista ao autor). Tal visão, condizente até mesmo com o apoio que levou Cardoso à agência, da Amil, não seria propriamente liberal, mas sim de mercado.

Nesse cenário, seria implausível supor que a minoritária Diope poderia influenciar o direcionamento mais geral de uma ANS dominada pelo grupo sanitarista. De fato, as principais evidências do período apontam para uma gestão que colocou a expansão e o aperfeiçoamento da regulação assistencial no centro da agenda regulatória. De forma particular, o diretor-presidente, Fausto dos Santos, trouxe com força as ideias de promoção da saúde e prevenção de riscos e doenças, caras ao sistema público.

O objetivo central dessa regulação assistencial, afastando-se do foco econômico-financeiro da gestão anterior, era

incorporar, às práticas assistenciais adotadas pelas operadoras, um modelo de promoção e prevenção que se afastasse do viés economicista, baseado em eventos/sinistros e na produção de procedimentos. Também aqui foi pensada uma aproximação com os princípios de universalidade, equidade e integralidade definidos como esfera do sistema público. (Matos, 2011:219)

O carro-chefe desse processo foi o Programa de Qualificação da Saúde Suplementar ( $R N$ no 139), programa que tinha como eixo central induzir a qualificação das operadoras, fomentando a transformação do modelo assistencial e a gestão de um modelo de atenção integral à saúde. Outras ações relevantes foram a $\mathrm{RN} \mathrm{n}^{\circ}$ 94, que impulsiona as empresas a adotarem os conceitos de promoção da saúde e prevenção de doenças para seus beneficiários, e a $\mathrm{RN} \mathrm{n}^{\mathrm{o}}$ 167, que ampliou a cobertura para consultas com nutricionista, fonoaudiólogo, terapeuta ocupacional e psicólogo. Outra deliberação importante foi a regulamentação da portabilidade de carências. Com vistas a coibir o processo de falsa coletivização, a ANS ainda regulamentou as administradoras de benefícios, que já atuavam no mercado e cresciam de forma desregulada (ANS, 2018).

Em resumo, é possível asseverar que as duas gestões sanitaristas vinculadas preponderantemente ao PT tiveram como marca e norte a 
regulação assistencial. Na primeira gestão, Fausto implementou uma agenda mais ambiciosa, que visava alterar o paradigma de assistência à saúde. Ao tentar induzir novas práticas às empresas, encontrou forte resistência do mercado. Considerado tecnicamente competente e politicamente habilidoso, o diretor-presidente foi capaz de liderar a pauta assistencial, fazendo o enfrentamento e as mediações necessárias com o mercado dentro e fora da agência.

\section{Período 2010-2012: inflexão liberal?}

A quarta gestão na ANS, coincidente com a transição entre os governos Lula e Dilma Rousseff, marca uma profunda inflexão na configuração política da agência. $\mathrm{O}$ grupo sanitarista ligado ao $\mathrm{PT}$, que havia predominado anteriormente, torna-se minoritário. Por outro lado, indivíduos de origens diversas chegam à ANS, conformando uma diretoria de perfil heterogêneo e mais liberal, conforme retratado na figura abaixo.

Figura 3

Rede entre diretoria colegiada da ANS, políticos e ministro da Saúde (2010-2012)

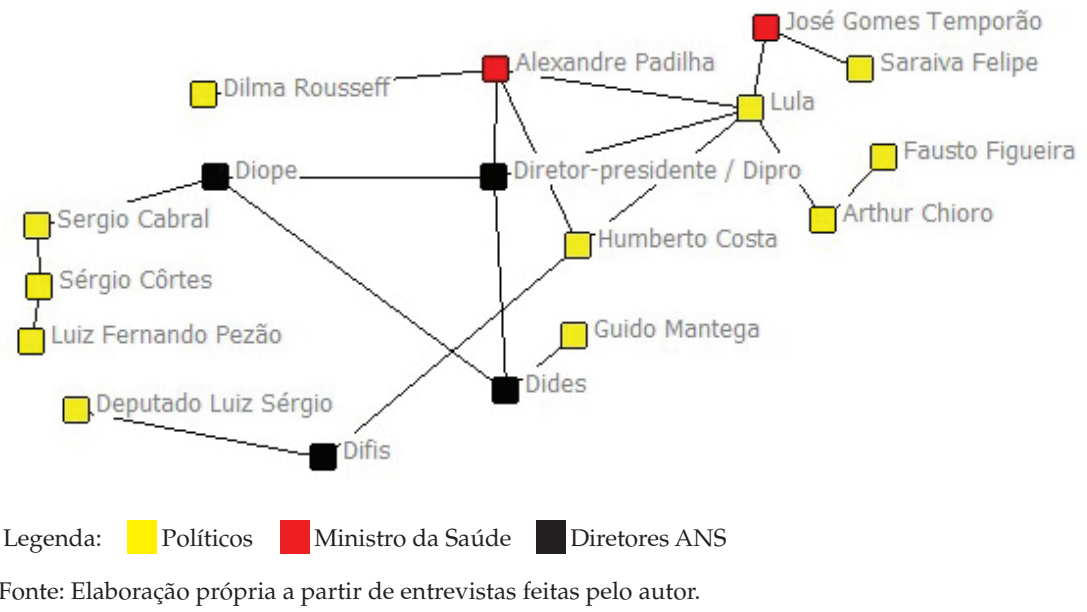

O PT perde bastante poder na agência, mantendo apenas uma diretoria sob seu controle, com a recondução de Sales ${ }^{5}$ à Difis. A Dipro, juntamente com a presidência, e a Dides saem de seu comando. A principal mudança na agência se dá justamente na presidência, que sempre havia sido ocupada por homens de confiança (e filiados) do partido do presidente da República. O novo diretor-presidente no- 
meado foi Mauricio Ceschin, um empresário sem ligação partidária, o que inclusive explica sua única relação política nas redes se dar com Lula, que o indicou. Ceschin, cuja trajetória está intimamente associada às empresas de planos de saúde, inclusive ocupando a presidência da Qualicorp no momento de sua indicação, é o primeiro diretor-presidente da ANS oriundo do mercado. Ceschin havia trabalhado também no Hospital Sírio-Libanês, que reúne um grupo de médicos influentes junto ao ex-presidente Lula e a diversos políticos. Assim, suas conexões vão além das operadoras de planos de saúde um dos articuladores de sua indicação, aliás, foi Roberto Kalil Filho, médico de Lula nesse mesmo hospital e ex-calouro de Ceschin na universidade (entrevista ao autor).

O padrão de comando na Diope não foi muito alterado, mesmo com a saída de Cardoso, que concluíra seu segundo mandato. Leandro Reis Tavares, que havia sido diretor adjunto de Cardoso e também tinha passagem pela Amil, assumiu essa diretoria. Havíamos identificado que a intermediação entre a Amil e a ANS já havia sido conduzida por Renan Calheiros, do PMDB, no período anterior ${ }^{6}$. Desta feita, quem operacionalizou essa indicação, renovando os vínculos entre partido e empresa, foi o PMDB do Rio de Janeiro, via governador Sérgio Cabral, conforme se vê na rede. O governador Cabral recebeu $\mathrm{R} \$$ 100 mil da Amil em sua campanha à reeleição de 2010 (TSE, 2010)7.

Esse episódio, com a consolidação do vínculo de diversas alas do PMDB com a Amil para influenciar a ANS, é revelador de que o partido começa a se afirmar mais definitivamente no jogo político da agência, o que reflete as transações políticas mais amplas levadas a cabo para a formação da coalizão governista. É na transição entre os governos Lula e Dilma Rousseff que o PMDB assume papel de maior destaque na coalizão, inclusive com a indicação do vice-presidente da República, Michel Temer.

Essas três indicações ocorreram ainda no governo Lula. Em 2011, já sob a presidência de Dilma e na gestão do novo ministro, Alexandre Padilha (PT), Bruno Sobral, gestor federal de carreira, assumiu a Dides com o apoio do ministro da Fazenda, Guido Mantega - daí sua conexão com o ministro ${ }^{8}$. Destaque-se que a Diges ficou sem diretor até 2012 - daí apenas aparecem 4 diretorias na figura. A ilustração abaixo traz o quadro de diretores do período. 
Quadro 3

Perfil diretoria colegiada ANS (2010-2012)

\begin{tabular}{lllll}
\hline Nome & Posição/Cargo & Governo & Partido & Instituição anterior \\
\hline $\begin{array}{l}\text { Mauricio } \\
\text { Ceschin }\end{array}$ & $\begin{array}{l}\text { Diretor-presidente } \\
\text { / Dipro }\end{array}$ & Dilma 1 & Qualicorp \\
Eduardo Sales & Diretor Difis & Dilma 1 & $\begin{array}{l}\text { Advocacia-Geral da } \\
\text { União }\end{array}$ \\
$\begin{array}{l}\text { Bruno Sobral } \\
\text { de Carvalho }\end{array}$ & Diretor Dides & Dilma 1 & DEM & Ministério da Fazenda \\
$\begin{array}{l}\text { Leandro Reis } \\
\text { Tavares }\end{array}$ & Diretor Diope & Dilma 1 & & Amil \\
\hline
\end{tabular}

Fonte: Elaboração própria a partir de entrevistas feitas pelo autor.

No cenário de uma diretoria colegiada reduzida, observa-se que apenas o diretor da Difis, Sales, representava a coalizão sanitarista anterior. Não à toa, ele mesmo afirmou que passou a ser corrente minoritária na agência (entrevista ao autor). À Diope, que costuma encarnar uma visão mais empresarial, foi agregada a Dipro, diretoria mais importante da agência, que, pela primeira vez, passou a ser comandada por um representante empresarial. A incógnita maior, para compreender o sentido da nova composição na agência, estaria, portanto, na Dides, agora encabeçada por um funcionário público federal. As informações apontam para mais um diretor de perfil liberal. Engenheiro com mestrado em Economia, com atuação no Ministério da Fazenda, que costuma ter uma posição de maior defesa do mercado no âmbito do governo, Sobral defendia uma regulação mais parcimoniosa e algumas pautas mais liberais, como a livre precificação no setor (entrevista ao autor). Outro fato que reforça seu caráter liberal é sua filiação ao Democratas (DEM), partido de cunho liberal e de oposição ao governo9. A Dides juntava-se, assim, à Dipro e à Diope, conformando, pela primeira vez, uma tríade mais liberal, e isolando a Difis dentro da agência.

Observa-se, assim, uma profunda reconfiguração política, que redistribuiu o poder na ANS, favorecendo uma visão mais liberal na saúde em detrimento dos grupos sanitaristas. Resta avaliar, entretanto, se a mudança na correlação de forças implicou, de fato, uma alteração no direcionamento geral da ANS, com medidas que revertessem a tendência de proteção ao consumidor via regulação assistencial. 
A análise do conjunto da obra desse período, ancorada na observação das resoluções aprovadas e no diálogo com atores dos dois lados da disputa, aponta, em que pesem algumas divergências, para um aprofundamento da regulação assistencial. De fato, alguns entrevistados chegaram a caracterizar esse período como o de maior regulação de assistência à saúde na história da ANS.

Destacamos as principais ações regulatórias dessa gestão. Uma delas é o Programa de Incentivo à Qualificação de Prestadores de Serviços na Saúde Suplementar (Qualiss), ( $\left.\mathrm{RN} \mathrm{n}^{\circ} 267\right)$, por meio do qual a ANS fixa parâmetros de qualificação dos prestadores. A ANS também implementou o pool de risco, que é o agrupamento de contratos de até 30 vidas para fins de determinação do reajuste anual. $\mathrm{O}$ objetivo dessa norma é minimizar a vulnerabilidade dos beneficiários dessa modalidade, já que a agência não estabelece o teto de reajuste para planos coletivos (ANS, 2018).

A principal medida da gestão na área assistencial, e aquela de maior impacto para o mercado, foi a determinação dos prazos máximos de atendimento ( $R N$ no 259). Com essa norma, as operadoras devem garantir a disponibilização de profissionais médicos dentro de certos parâmetros temporais. A partir do monitoramento do cumprimento dessa norma pelas operadoras, diversas sanções podem ser impostas pela agência, sendo a mais rigorosa a suspensão da comercialização de novos planos. Em julho de 2012, a ANS suspendeu a comercialização de 268 planos de saúde de 37 operadoras (ANS, 2018). O anúncio dos planos suspensos é a medida de maior repercussão midiática da agência.

Para além de sua conspicuidade, é possível afirmar que a medida consubstanciou o segundo momento de enfrentamento ao mercado, após a primeira gestão de Fausto, visto que o impacto para as empresas foi grande. Um representante empresarial afirmou que os custos dessa resolução não foram recuperados até hoje pelas indústrias (entrevista ao autor). Um ex-dirigente da agência que trabalha em consultoria do setor disse que

a questão do tempo de atendimento é uma coisa que na prática, eu estou vendo aqui, que funcionou, ou seja, as operadoras estão muito preocupadas em manter tempos de atendimento básicos. Então correm atrás disso para não ter [...]. O medo é muito grande, com razão, né, de ter uma suspensão de comercialização etc. (entrevista ao autor) 
Para além das pautas assistenciais, destaque-se que a agência tinha muita dificuldade em garantir que as operadoras fizessem o devido ressarcimento ao SUS. Isso começa a ser equacionado no período, de modo que mais de R\$ 152 milhões foram repassados ao Ministério da Saúde no biênio 2011-2012, o que representou aproximadamente $65 \%$ a mais de todo o valor arrecadado pela ANS desde sua criação (ANS, 2018). Conforme resume um funcionário da agência, ao falar da gestão Ceschin, "foi ele que bota o ressarcimento ao SUS de volta nos trilhos" (entrevista ao autor).

Evidentemente, há divergência, especialmente entre os sanitaristas, sobre o que teria sido, preponderantemente, a agenda de Ceschin no período. Sendo esse período um momento crucial de nossa análise, vale trazer a lume alguns dos argumentos levantados.

Um primeiro ponto é que a vinda de Ceschin teria como meta organizar e expandir as administradoras de benefícios, modalidade empresarial de onde ele era egresso. No entanto, as resoluções que regulamentaram essa modalidade foram aprovadas ainda na gestão do sanitarista Fausto. Além disso, alguns sanitaristas reconhecem que a regulamentação ao menos garantiu maior proteção aos beneficiários (entrevista ao autor).

A outra questão mais estrutural destacada seria a concentração de mercado ocorrida no período, particularmente a entrada do capital estrangeiro, como no caso da autorização dada pela ANS para a compra da Amil pela UnitedHealth em 2012. Segundo relatos, os processos de aquisição no setor eram combatidos na ANS por favorecer a prática oligopolista. No entanto, na gestão Ceschin, essa atitude teria mudado, sendo o principal exemplo a compra da Amil, a maior da história do setor (entrevista ao autor).

Realmente, as notícias têm mostrado que as aquisições no setor têm se intensificado recentemente, especialmente com a entrada de fundos estrangeiros. A NotreDame Intermédica foi comprada pelo fundo Bain Capital em 2014, enquanto houve relatos, em 2016, de negociações para que os fundos Carlyle e GIC, que têm participação na Rede D'Or, façam uma oferta pela administradora de benefícios Qualicorp ${ }^{10}$. Por outro lado, diversas Unimeds, inclusive as maiores, têm falido e deixado o mercado. 
Se é verdade que a tendência concentradora, com a financeirização da saúde suplementar, tem se intensificado, também é certo que esse processo vem ocorrendo desde a regulamentação do setor, que trouxe consigo um enxugamento do mercado. A própria Amil vem adquirindo diversas empresas desde 2002 pelo menos. Dentre elas, destaca-se a multimilionária compra da Medial, ainda em 2009. A Bradesco Saúde passou por processo semelhante, na medida em que a empresa comprou, entre 2002 e 2010, 23 empresas $^{11}$. Além disso, outras empresas, como a própria Qualicorp, já tinham participação de capital estrangeiro antes da transação da $\mathrm{Amil}^{12}$.

Evidentemente, a compra da Amil chamou a atenção por sua magnitude. Além disso, a autorização da ANS foi realizada em apenas 15 dias e no final do mandato de Ceschin e Tavares. Mesmo reconhecendo o impacto da decisão sobre a Amil, não se pode afirmar que se tratou de medida inédita, assim como não se tem informação de nenhuma regra que tenha sido alterada pela gestão Ceschin que pudesse favorecer, dali em diante, esse tipo de transformação estrutural. Ainda sobre o caso da Amil, a autorização da transação foi aprovada pelos cinco diretores da agência, incluindo Sales, da Difis ${ }^{13}$.

Quem, de fato, mudou as regras mais gerais do setor, abrindo-o para o mercado estrangeiro, foi a presidente Dilma, ao sancionar a Lei $\mathrm{n}^{\mathrm{o}}$ 13.097, que autoriza investimentos externos, inclusive controle, na saúde, como em hospitais e clínicas. A emenda que incluiu esse ponto numa medida provisória foi do deputado federal Manoel Junior (PMDB-PB), que recebeu recursos da Bradesco Saúde na campanha eleitoral de 2014 (TSE, 2014). Ressalte-se que o governo manteve a emenda, a despeito do parecer da Advocacia-Geral da União recomendando o veto parcial ao artigo por considerá-lo inconstitucional.

Por fim, há o caso da regulamentação dos artigos 30 e 31 da Lei dos Planos de Saúde, que trata dos direitos de aposentados e demitidos. Segundo relatos, a $R N$ oo 279 representou um retrocesso, pois permitiu que essas duas categorias fossem alocadas em contratos específicos, separados da massa geral de trabalhadores da empresa, tornando os reajustes maiores. Este, sim, parece ser um caso concreto de norma do período que debilitou a proteção dos beneficiários. Foi com esse entendimento que Sales votou contrariamente à medida, divergindo em relação aos outros três diretores. 
Apesar de não termos identificado, ao longo da gestão Ceschin, evidências robustas de ações ou normas que pudessem ter alterado o curso anterior da agência, decidimos, com vistas a emprestar maior rigor à investigação, proceder a uma análise típica do fenômeno da porta giratória (revolving door).

A porta giratória diz respeito à migração de funcionários entre os setores público e privado. Tal fenômeno gera o risco de que o comportamento desses atores seja determinado pela perspectiva de transição entre esses dois polos. Assim, um representante do empresariado pode, uma vez exercendo a função governamental, dirigir suas ações para beneficiar o setor privado, ao qual ele possivelmente retornará. Nas palavras de Gormley (1979:666), “A hipótese da porta giratória afirma, com efeito, que um intercâmbio de funcionários nesses termos influencia o comportamento do voto numa agência reguladora" (Tradução livre).

Gormley (1979) analisou os votos divergentes de dois anos na agência norte-americana Federal Communications Commission (FCC) para identificar se o padrão de votos dos dois diretores com passagem pelo setor privado destoava do resto da diretoria. Adotamos a mesma metodologia, observando o padrão de votos na ANS durante a gestão Ceschin. Essa parece ser a maneira mais direta de testar o efeito da porta giratória com a mudança na composição da diretoria colegiada. Em outras palavras, pessoas oriundas do mercado ou de posição liberal tenderiam a votar conjuntamente e em oposição ao grupo sanitarista. Em nosso caso, estamos interessados em identificar se Sales, da Difis, votava consistentemente em oposição aos outros três diretores, de perfil mais liberal.

Para a verificação do padrão de votação da diretoria da ANS, consultamos o rol completo de resoluções normativas no próprio site da agência. Para cada resolução, identificamos a data da reunião em que foi aprovada e checamos as respectivas atas para conferir os diretores presentes e o voto de cada um. Excluindo da população analisada as resoluções atinentes ao regimento interno, construímos uma base de dados com 211 resoluções com impacto regulatório entre 2004 e 2014.

A análise dos dados vem ao encontro de nossas suposições. Não foi possível realizar um teste do agrupamento dos votos, pois, das 68 re- 
soluções normativas aprovadas durante a gestão Ceschin, em apenas uma houve divergência. Foi justamente na já mencionada votação sobre a regulamentação dos direitos de demitidos e aposentados, quando Sales foi voto divergente. Assim, Sales, que era o único diretor vinculado ao grupo sanitarista do PT e afirmara, em entrevista, que havia se tornado a corrente minoritária na agência, votou consistente e convergentemente com os outros diretores nas demais ocasiões. Essa votação em bloco revela uma unidade na atuação dessa gestão, o que reforça os indícios de que não houve inflexão de viés liberal na ANS no período.

Sem dúvida, houve, no período 2010-2012, uma substantiva mudança no perfil do alto escalão da ANS, com o predomínio de forças mais liberais e ligadas ao mercado. Essa recomposição, no entanto, não parece ter provocado uma alteração no curso mais geral da agência. As resoluções aprovadas não indicam uma flexibilização nas regras ou uma regulação mais branda. Ao contrário, nesse período são intensificadas algumas regulações assistenciais que beneficiam os consumidores, impondo custos às empresas.

A despeito de divergências, boa parte dos entrevistados, inclusive de viés sanitarista, corrobora essa visão. Um ex-dirigente sanitarista, após reconhecer que o mercado foi "hegemônico" no período, afirma que "na época do Mauricio Ceschin [...] saiu essa regra, por exemplo, do tempo de atendimento, que eles [empresários] têm um verdadeiro pavor". Outra entrevistada, ligada aos sanitaristas petistas, vai na mesma linha ao tratar de Ceschin: "Eu tenho impressão que [...] ele fez um mandato totalmente consumerista" (entrevista ao autor). Concluímos, assim, que a gestão Ceschin representou mais uma continuidade do processo político-regulatório anterior do que uma inflexão liberal no âmbito da ANS. As diferenças, assim, são mais de ritmo do que de direção.

\section{Período 2013-2014: uma gestão de transição}

O último período analisado engloba apenas os anos de 2013 e 2014, pois André Longo, que liderou a ANS após a saída de Ceschin, já estava na agência e só pôde exercer a presidência por mais dois anos. Longo teria a seu lado Sobral e Tavares, que teve seu mandato renovado. Sales também deixa a agência. Como foi um período de alta rotatividade na diretoria, as ilustrações do período mostram apenas três diretores. 
Figura 4

Rede entre diretoria colegiada da ANS, políticos e ministro da Saúde (2013-2014)

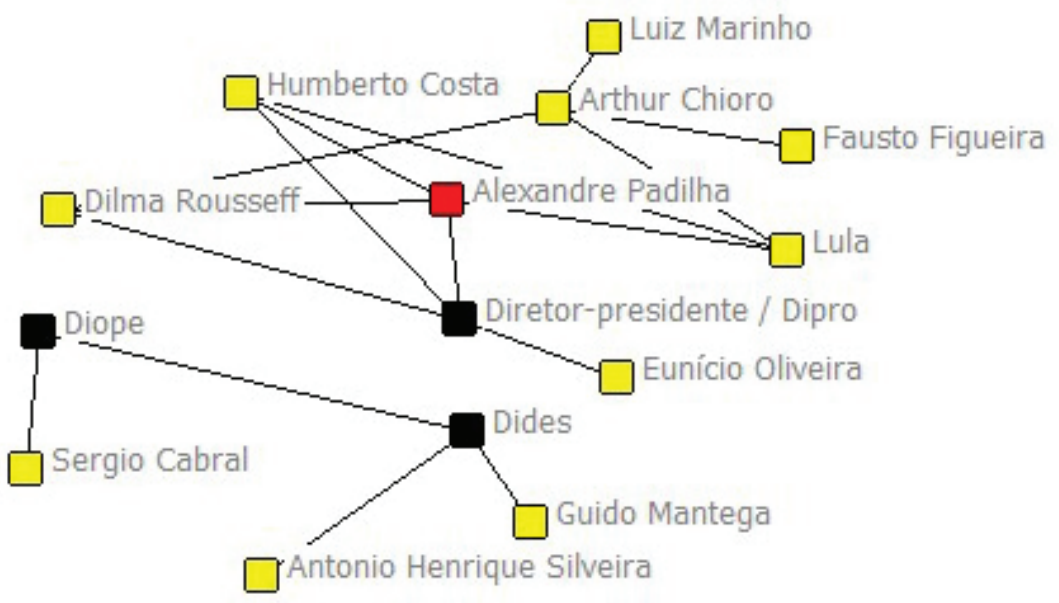

Legenda: Políticos Ministro da Saúde Diretores ANS

Fonte: Elaboração própria a partir de entrevistas feitas pelo autor.

Quadro 4

Perfil diretoria colegiada ANS (2013-2014)

\begin{tabular}{lllll}
\hline Nome & Posição/Cargo & Governo & Partido & \multicolumn{1}{c}{ Instituição anterior } \\
\hline André Longo & $\begin{array}{l}\text { Diretor-presidente } \\
\text { / Dipro }\end{array}$ & Dilma 1 & $\begin{array}{l}\text { Sindicato dos Médicos/ } \\
\text { PE }\end{array}$ \\
$\begin{array}{l}\text { Leandro Reis } \\
\text { Tavares }\end{array}$ & Diretor Diope & Dilma 1 & Amil \\
$\begin{array}{l}\text { Bruno Sobral } \\
\text { de Carvalho }\end{array}$ & Diretor Dides & Dilma 1 & DEM & Ministério da Fazenda \\
\hline
\end{tabular}

Fonte: Elaboração própria a partir de entrevistas feitas pelo autor..

Em termos de composição política, esse período marca uma relativa continuidade com a gestão anterior. Por um lado, a permanência de Sobral e de Tavares numa diretoria colegiada composta por apenas três diretores revela que as forças liberais e empresariais permaneciam majoritárias na agência. Essa distribuição de poder, no entanto, deve ser matizada e contrabalançada pela nomeação de Longo à presidência da ANS. Longo, que havia militado com o ministro da Saúde, Alexandre Padilha, no movimento médico, representava o retorno do PT ao comando da agência. Frise-se, no entanto, que a indi- 
cação de Longo representou mais um aceno à categoria médica, em cujo sindicato de Pernambuco fez carreira, do que um retorno dos sanitaristas. De todo modo, ele poderia funcionar como um contrapeso às inclinações mais liberais dos outros dois dirigentes. Por outro lado, outros elementos desse período apontam para um fortalecimento do campo empresarial e do PMDB, que, no caso, funcionam como dois lados da mesma moeda.

Além da indicação na Diope, o PMDB foi responsável pela nomeação de Elano Figueiredo como diretor da Diges ainda em 2013. Figueiredo era vinculado à Hapvida, maior operadora da região Nordeste, com sede no Ceará. Não à toa, sua indicação deveu-se ao senador cearense pelo PMDB, Eunício Oliveira. O nome de Figueiredo não aparece nas redes, pois ele renunciou com menos de dois meses no cargo, após a Comissão de Ética Pública da Presidência da República recomendar sua demissão por haver omitido do currículo apresentado no Senado sua atuação em empresas do setor. Assim, não fosse o crasso erro de Figueiredo, a agência teria tido em seus quadros mais um nome oriundo do mercado, replicando, em alguma medida, a distribuição de poder na gestão anterior.

Um último ponto que reforça as informações do perfil de um diretor diz respeito à outra confusão quando da indicação de um nome à diretoria da ANS. Ainda em 2014, Dilma indicou o nome de Sobral para recondução à diretoria da agência. No entanto, menos de duas semanas depois, retirou a indicação, pois ele teria apoiado tecnicamente Eduardo Cunha (PMDB/RJ) na redação da justificativa de uma medida provisória que perdoava dívidas de operadoras (entrevista ao autor).

Embora o jogo continuasse a pender para o lado liberal, a própria inconstância no alto escalão da ANS no período não dava condições para qualquer tipo de redirecionamento. Além disso, a presidência da agência havia mudado de mãos. Por outro lado, o novo diretor-presidente da agência tampouco conseguiu criar uma agenda factível capaz de aprofundar a regulação assistencial existente. A análise do relatório de gestão parece confirmar essa impressão, pois boa parte das ações elencadas referia-se ao aperfeiçoamento de iniciativas anteriores. Assim, essa gestão caracterizou-se mais como um período de transição, sem grandes mudanças e mesmo sem uma linha clara de atuação, conforme sintetiza o presidente de uma operadora: 
[...] um período mais de transição, né? Em que acho que se tentou talvez dar conta de muitos projetos ao mesmo tempo. Então, enfim, acho que talvez não tenha nessa do André Longo na minha memória nada que tenha marcado muito profundamente a gestão. Mas acho que ela deu sequência ao que vinha sendo desenhado nas gestões anteriores. (entrevista ao autor)

\section{FATORES POLÍTICOS, INSTITUCIONAIS E SETORIAIS DETERMINANTES DA INFLUÊNCIA NA ANS}

A alteração no pêndulo das distintas forças políticas internas à agência não parece ter provocado mudanças bruscas na direção mais geral da regulação da ANS. Nesse sentido, é importante explorar outros fatores, de ordem política, institucional e relativa à especificidade do setor e do objeto regulado, que ajudam a explicar a não inflexão liberal na agência. Com isso, esperamos aportar contribuições teóricas sobre como instituições, politics e policies (e o quanto elas são issuespecific) se inter-relacionam e impactam na configuração de um setor de políticas públicas (Couto e Arantes, 2006).

A estabilidade na política pública é uma característica da regulação na ANS. De fato, identificamos que, mesmo no período majoritariamente sanitarista, os liberais acabaram pactuando em torno dessa agenda. A tabela 1 é uma complementação da análise anterior que fizemos do padrão de votos na gestão Ceschin. Decidimos estender essa investigação para todas as gestões da ANS entre 2004 e 2014.

Tabela 1

Padrão de votos nas Resoluções Normativas com impacto regulatório

\begin{tabular}{lccccc}
\hline & 2004-2006 & 2007-2009 & 2010- 2012 & 2013-2014 & Total \\
\hline Unanimidade & 49 & 50 & 67 & 40 & 206 \\
Divergente & 4 & 0 & 1 & 0 & 5 \\
Quem divergiu & $\begin{array}{c}\text { Maria Stella } \\
\text { Gregori }\end{array}$ & - & Eduardo Sales & - & - \\
\hline Total & 53 & 50 & 68 & 40 & 211 \\
\hline
\end{tabular}

Fonte: Elaboração própria a partir de entrevistas feitas pelo autor.

A análise dos dados é bastante surpreendente, pois mostra que as distintas perspectivas não se traduziram em votos díspares nas prin- 
cipais regulações da agência. Ao contrário, a esmagadora maioria das votações ocorreu por unanimidade. Curiosamente, a maior divergência verificada não se dá no contexto da oposição entre sanitaristas e liberais, mas sim por parte da representante dos consumidores em relação aos outros diretores da agência. Mas mesmo assim a divergência é residual. Na segunda gestão (2004-2006), Gregori, oriunda do Procon-SP, divergiu de seus colegas em 7,5\% das decisões. Depois disso, entre 2007 e 2014, o único voto divergente foi o já mencionado de Sales na questão dos demitidos e aposentados. Os liberais alocados na Diope jamais votaram em oposição aos sanitaristas, nem quando eram majoritários nem quando eram minoritários. Em realidade, é possível afirmar que o caso desviante nas votações na ANS não diz respeito aos grupos políticos, mas à própria pessoa de Gregori.

A análise do padrão de votos relativiza o fenômeno da porta giratória, ao menos do ponto de vista de seus efeitos em termos de posicionamento dissonante dos indivíduos liberais ou oriundos do mercado perante as principais decisões da agência. Cabe explicarmos, assim, quais fatores contribuíram para a não inflexão liberal na agência.

O primeiro elemento, que diz respeito a uma faceta da especificidade do setor, é a heterogeneidade do mercado. Em que pese haver interesses comuns que podem favorecer o empresariado como um todo, a variação de formatos institucionais das operadoras de planos de saúde $^{14}$ envolve também interesses distintos dentro do setor, a depender do nicho explorado e do próprio modo de atuação no mercado. Conforme exemplifica um informante, o setor é composto por

um conjunto de empresas que não tem uma linha única. E assim, o fim do reajuste não é uma unanimidade no setor. Até porque beneficiaria muito mais uma Amil do que, por exemplo, o Bradesco. E certamente não beneficiaria a Qualicorp (entrevista ao autor).

Um funcionário da ANS reafirma essa característica da saúde suplementar, chamando a atenção justamente para o contraste entre a menor uniformidade de interesses do lado do mercado em relação aos beneficiários:

Agora, o que é interessante, é muito interessante, isso é realmente uma coisa bastante peculiar no setor é que, quando você fala de prestadores, você fala assim: vou negociar determinado aspecto regulatório com os 
prestadores, estou pensando em fazer isso e tal. Você nunca encontra um nível de consenso muito forte entre eles, seja operadora, seja prestador. Talvez os beneficiários, eles ainda tenham um conjunto de posições assim mais homogêneas. (entrevista ao autor)

Verifica-se, assim, um elemento a reforçar o caráter caleidoscópico dos interesses presentes no setor, concorrendo para dificultar o consenso no mercado e a possibilidade de uma ação mais concertada no âmbito da ANS. Pensando na agência, observamos que a heterogeneidade é grande. Houve diretores ligados à Amil na Diope, um diretor-presidente oriundo do mercado vinculado a uma administradora de benefício e um diretor mais liberal oriundo do próprio governo.

Tratando da ausência do consenso do mercado sobre algumas políticas públicas específicas, um ex-diretor da agência simula o raciocínio de um mandatário da agência diante da possibilidade de implementar uma agenda de corte liberal, mas benéfica a apenas uma fração do mercado:

Por que eu vou me desgastar com uma coisa que eu vou desagradar todo o status quo político, eu vou desagradar o meu servidor, eu vou desagradar os sanitaristas, eu vou desagradar os consumeristas, né, eu vou desagradar o presidente da República e o ministro? E do outro lado eu vou agradar um dos atores ou dois dos atores? Você fala: pô, eu não vou entrar nessa. (entrevista ao autor)

Outro fator extremamente forte, de cunho institucional, a bloquear iniciativas mais liberalizantes na ANS é sua burocracia sanitarista. Embora tardiamente, a agência logrou consolidar seu corpo profissional ao longo do tempo. Os concursos públicos realizados, oferecendo altos salários e exigindo uma grande expertise, forjaram um quadro técnico altamente qualificado e fomentaram o esprit de corps na ANS. Conforme explicou uma funcionária da agência,

Ali as pessoas vestem a camisa mesmo. Porque, primeiro, querem garantir o seu emprego, tá? Garantir uma boa ocupação, um conforto ali dentro. E depois porque existe a crença de que a agência desempenha uma importante função na sociedade [...]. O salário é bom, eu tenho boas condições de trabalho aqui, eu sou reconhecida na sociedade pelo que eu faço, porque o meu trabalho é importante. (entrevista ao autor) 
A crescente institucionalização da ANS pode ser vista tabela 2 com a consolidação dos funcionários da agência conectados à elite do setor, bem como com o aumento contínuo da proporção de concursados, que, aliás, passaram a ocupar cargos cada vez mais importantes - a ponto de alcançar postos de diretoria a partir de 2014.

Tabela 2

Dados sobre funcionários da ANS nas redes da elite do setor

\begin{tabular}{lccccc}
\hline & $2000-2003$ & $2004-2006$ & $2007-2009$ & $2010-2012$ & 2013-2014 \\
\hline $\begin{array}{l}\text { № de funcionários } \\
\text { da ANS }\end{array}$ & 15 & 39 & 45 & 40 & 29 \\
$\begin{array}{l}\text { Proporção na rede } \\
\text { № de concursados }\end{array}$ & $13 \%$ & $30 \%$ & $33 \%$ & $28 \%$ & $20 \%$ \\
$\begin{array}{l}\text { Proporção de } \\
\text { concursados }\end{array}$ & $0 \%$ & 7 & 14 & 14 & 13 \\
\hline
\end{tabular}

Fonte: Elaboração própria a partir de entrevistas feitas pelo autor.

Uma burocracia forte tem maior capacidade de negociação e barganha, reduzindo o espectro de ações possíveis levadas a cabo pelos dirigentes máximos de uma instituição. Cabe inquirir apenas para que lado penderá a burocracia. $\mathrm{Ou}$, nos termos dos estudos organizacionais, qual seria sua missão. Nas palavras de Wilson (1989:95),

Quando uma organização tem uma cultura que é largamente compartilhada e fortemente endossada tanto por funcionários como por dirigentes, dizemos que a organização tem um senso de missão (Tradução livre).

Na ANS, o direcionamento foi para o campo sanitarista, conforme atestam entrevistados dos dois campos da disputa e do que dá prova uma recente ação no âmbito da diretoria colegiada.

Com os primeiros concursos públicos em 2005 e 2007, a ANS trocou a totalidade de seu quadro técnico, que hoje acumula mais de dez anos de experiência. Como a agência era dominada no período por sanitaristas, liderados por Fausto, a formação dos novos servidores seguiu essa linha. Como reconheceu um alto funcionário ligado a esse grupo, "O processo de formação tinha muito SUS, relação público-privado, fizemos uma certa catequese, né, nesse processo" (entrevista ao autor). 
Esse momento fundante é particularmente relevante, pois permite que a burocracia seja moldada mais facilmente, a despeito de outros fatores. Wilson (1989) reflete de forma certeira sobre esse ponto:

Mas às vezes uma organização é dotada de um senso de missão a despeito dos objetivos ambíguos, das predisposições pessoais, dos grupos de pressão, e dos imperativos do contexto. Isso geralmente ocorre durante a experiência formativa da organização, uma experiência moldada e interpretada por um fundador que impõe sua visão à primeira geração de funcionários de tal maneira que afeta profundamente as gerações seguintes. (Wilson, 1989:96, tradução livre)

Essa característica da institucionalidade da ANS também foi confirmada pelo grupo mais liberal. Um representante dessa ala afirmou que a seleção na agência priorizou o conhecimento técnico sanitarista em detrimento de outras disciplinas que poderiam tornar a regulação mais "equilibrada". Ele ressaltou que a Diope conseguiu atrair pessoas com maior racionalidade econômica, tornando-a menos sanitarista (entrevista ao autor).

Ambos os entrevistados identificam as consequências desse processo para o jogo político interno da agência. Conforme aponta o sanitarista:

O fato de você ter trocado 100\% dos servidores entre 2005 e 2007 gerou uma, digamos, uma estabilidade, uma estabilização que é difícil de romper, entendeu? Para ir para lá e fazer isso [introduzir agenda liberalizante], o cara tem que ser bom, conseguir enfrentar. Primeiro, precisa ter uma agenda e, segundo, precisa ter capacidade de enfrentamento para poder reverter ou superar as dificuldades colocadas pelos próprios funcionários da casa. (entrevista ao autor)

Ao menos dois ex-diretores de viés liberal reconheceram a dificuldade de fazer avançar questões mais liberalizantes na ANS. Um deles explanou esse fato, narrando que

Tudo que você faz que não se coaduna com uma visão consumerista e sanitarista vai ter uma resistência muito grande do servidor interno que vai ver aquilo como uma sacanagem. Você está ali fazendo sacanagem porque você foi indicado por não sei quem. [...] Existe uma visão institucional de protecionismo. (entrevista ao autor) 
Um acontecimento mais recente e inédito na agência ajuda-nos a atestar o peso desse fator institucional. A diretoria colegiada era composta, até o fim de 2016, por duas sanitaristas que estão na agência desde o início, dois representantes do mercado e uma quinta servidora concursada, mas que havia sido apoiada pelo senador Eunício Oliveira (PMDB-CE). Havia dúvidas, assim, para que lado penderia a ANS. A incerteza foi sanada durante a $445^{\mathrm{a}}$ reunião da diretoria colegiada, ocorrida em 1/6/2016 ${ }^{15}$. Com a renúncia do diretor da Diope ligado à Amil, Simone Freire, servidora ligada ao senador peemedebista, compôs com as outras duas diretoras sanitaristas, alterando a geopolítica da agência. Contra o voto isolado do diretor-presidente, José Carlos Abrahão ${ }^{16}$, as três diretoras o destituíram da diretoria mais poderosa, a Dipro, designando-o para a fraca Diges. Destaque-se ainda que, em sua justificativa, a diretora Martha Oliveira trouxe à baila sua condição de servidora da agência e argumentou que o diretor-presidente ocupar a Diges é uma velha demanda dos funcionários. Não resta dúvida, portanto, que a burocracia sanitarista da ANS, especialmente ao ocupar os postos mais altos da agência, serve como contrapeso a iniciativas liberais.

Outros dois elementos relevantes, também de ordem institucional, são o mecanismo de positive feedback e o caráter microrregulatório da agência. O primeiro ponto está ligado à noção de path dependence, ou seja, a ideia de que políticas públicas, uma vez implementadas, condicionam os processos políticos e a própria trajetória da política pública. Assim, uma política iniciada em certa época tomará determinado rumo, sendo difícil alterá-la posteriormente, na medida em que os benefícios do arranjo inicial crescem na comparação com as alternativas possíveis (Pierson, 2004).

No caso da ANS, é importante retroceder até 1998, época da regulamentação do setor, para compreender esse mecanismo. Diversas medidas de proteção ao consumidor introduzidas pela Lei dos Planos de Saúde, como o teto de reajuste e o plano-referência, estão consolidadas e são defendidas por diversos grupos. Nesse sentido, torna-se cada vez mais difícil e custoso, politicamente, tomar medidas que flexibilizem essas garantias. Um ex-diretor da agência de viés liberal afirmou que, embora considere disfuncional a manutenção do controle de reajustes nos planos individuais, seria muito difícil retroagir nessa questão, agora que se tornou uma proteção ao consumidor (entrevista ao autor). 
Em relação à microrregulação na ANS, vale pontuar que a lei trouxe importantes mudanças, mas não dotou a agência de capacidade regulatória para fazer alterações significativas no setor. De acordo com um ex-diretor da agência, ao não se definir a saúde privada como uma concessão, como o setor de petróleo, por exemplo, a ANS não tem capacidade de definir normas macroeconômicas que, de fato, orientem a atuação das empresas no setor. Assim, fica-se restrito à microrregulação de viés econômico. Por outro lado, essa mesma lei já pormenorizou as principais proteções ao consumidor. Assim, questões centrais que os grupos liberais gostariam de ver modificadas, como liberação de reajuste e segmentação na oferta de planos, requereriam alteração legal e, portanto, estão fora da alçada da agência. Não à toa, frequentemente se noticia a discussão dessas questões na Casa Civil ou no Congresso Nacional. Um ex-diretor da agência, ao comentar os objetivos últimos do empresariado na saúde suplementar, corroborou que "O interesse do setor está na 'subsegmentação', que é o que poderia fazer com que eles expandissem, naturalmente calcada em algum nível de subsídios do governo" (entrevista ao autor).

Por fim, vale analisar o papel da política para além das indicações políticas, levando-se em conta o clima político, a mídia e a trajetória profissional. O clima político no governo não favorecia mudanças de cunho mais liberal. Como a ANS segue uma toada incremental, talvez apenas um choque externo, vindo do Executivo ou do Legislativo, pudesse fazer a agência mudar suas políticas. E, apesar dos conflitos internos, era improvável que a coalizão governamental liderada pelo PT desde 2003 provocasse a ANS nesse sentido. Tanto é que apenas com a troca do governo Dilma, em 2016, forjou-se um movimento, capitaneado pelo novo ministro da Saúde, Ricardo Barros - deputado federal pelo Partido Progressista (PP) do Paraná licenciado -, para tentar convencer a agência a flexibilizar as regras de cobertura do rol de procedimentos.

A mídia também parece confluir com o clima político, como apontam diversos entrevistados, ao citar matérias críticas de $O \mathrm{Globo}^{17}$ ou artigos de professores, como Ligia Bahia e Mario Scheffer. Um ex-diretor de viés mais liberal resume bem esse ponto:

Assim, eu acho que é sempre mais fácil, do ponto de vista de discutir com a mídia, de discutir com os políticos, você fazer uma política próconsumerista do que fazer uma política de liberalização. [...] Eu não acho que tenha tido uma inflexão. [...] Eu acho que não tinha clima político 
talvez [...]. Eu acho que não tinha, quem entrou, no caso do Mauricio, sofreu na entrada, muita porrada, né? Tomou muita porrada dos sanitaristas, quase que uma porrada preventiva pro cara não fazer nada de diferente. (entrevista ao autor)

Essa última questão assinalada pelo entrevistado, referente à trajetória de Ceschin, que presidiu a ANS entre 2010 e 2012, merece maior desenvolvimento. Diversos atores do setor apontaram para esse fato contraintuitivo de a origem no mercado poder ter um peso negativo e contraproducente, na perspectiva de quem espera a implementação de medidas liberais. Nesse sentido, as indicações políticas teriam, sim, um peso, mas contrário ao esperado. Conforme relatou um alto dirigente sanitarista,

na verdade, assim, né, eu sempre, já conversei isso com vários diretores de empresas, essa coisa de você colocar um operador do mercado diretamente é uma bobagem, né, porque você gera suspeição sobre todos os atos do indivíduo e não é por ali que ele consegue. Tanto que na época do Mauricio Ceschin [...] saiu essa regra, por exemplo, do tempo de atendimento, que eles têm um verdadeiro pavor. (entrevista ao autor)

A burocracia sanitarista da ANS vem reforçar esse mecanismo da trajetória profissional, o que é notado por outra servidora com passagem pela agência, que compartilha a mesma opinião sobre Ceschin: "Eu tenho impressão que, para não ficar sob suspeição, ele fez um mandato totalmente consumerista. Totalmente. Senão ele não se sustentava lá dentro, entendeu?" (entrevista ao autor).

Tendo passado em revista os fatores que contribuíram para obstaculizar inflexões liberais na ANS, vale discutir três elementos institucionais que explicam o caráter uníssono da atuação da agência. Isso é importante, pois não apenas a ANS não alterou seu rumo, como, mesmo antes disso, os liberais, quando eram minoritários, compuseram com os sanitaristas. Em parte, isso tem a ver com outra faceta da microrregulação. As amarras à atuação mais abrangente da ANS não se dão apenas em questões que beneficiariam o empresariado, mas também em aspectos que privilegiariam os consumidores, impondo uma regulação num nível muito microscópico. $\mathrm{O}$ arco estreito de decisões possíveis acaba por funcionar como um estímulo ao compromisso. Essa característica aparece na fala de um ex-diretor vinculado aos sanitaristas, que critica a inexistência de um poder de outorga 
na agência para a definição estrutural da atuação do setor privado na saúde: "Você fica prisioneiro do consenso. Por quê? Porque nós seguimos, exatamente, esse vício de origem, essa Constituição, essa norma constitucional, que, a meu ver, é um pouco manca" (entrevista ao autor).

Agregue-se a isso o fato de estar incorporada na missão institucional da agência a ideia de que a regulação deve ser mediada e equilibrada entre os diversos atores do setor. As entrevistas explicitam que há uma clareza geral sobre esse caráter moderador da ANS. Uma ex-funcionária da agência afirma que

Na verdade, na verdade, essa é a grande diferença entre órgão de defesa do consumidor e a agência. Porque a agência tem uma percepção também que o mercado tem que sobreviver. Então o mercado também não pode só ser entubado, entubado goela abaixo de tudo. Porque ele tem um custo. (entrevista ao autor)

Assim, a ANS concilia o éthos sanitarista com a visão de que o mercado de saúde suplementar deve prosperar. Isso explica, por exemplo, o fato de um dos ex-diretores sanitaristas defender que os planos coletivos não tenham os reajustes definidos pela ANS, reivindicação básica de diversos consumeristas e sanitaristas (entrevista ao autor). Essa concepção de regulação mediada aproxima os distintos polos e favorece o consenso.

O terceiro fator institucional tendente a harmonizar as decisões diz respeito ao desenho institucional da agência. Inicialmente, o próprio fato de a ANS deliberar de forma colegiada já induz à busca de consenso entre as partes. No entanto, a ANS tem uma peculiaridade, que é a fragmentação entre as diretorias. Esse insulamento deve-se ao processo de designação dos diretores para diretorias específicas. Por esse mecanismo, o diretor na ANS não tem apenas um cargo político, tornando-se também o responsável técnico por sua área, gerando uma especialização e a decorrente assimetria de informação entre os diretores. Nas palavras de um funcionário da agência, o parecer de um diretor em relação a determinado tema acaba constituindo-se a "manifestação do diretor técnico da área", tornando-se mais difícil para outro diretor barrar a proposta (entrevista ao autor). 


\section{CONSIDERAÇÕES FINAIS}

Buscamos contribuir com a literatura sobre política, interesses e burocracia. Empiricamente, fizemos um amplo esforço qualitativo para revelar o modus operandi que cerca as indicações políticas numa agência reguladora no país. Do ponto de vista da literatura de agências reguladoras, demonstramos, a partir do jogo político por trás das nomeações na ANS, que o desenho institucional das agências reguladoras não lhes garante ampla autonomia. As agências, assim como outros órgãos governamentais, estão inseridas e sofrem influência das diversas teias de relações que envolvem políticos, burocratas e empresários.

Mas entendemos que nossa principal contribuição diz respeito aos fatores que explicam a influência ou o resultado das políticas regulatórias levadas a cabo pela ANS. Ao reconstituir as disputas políticas na história da agência, visando aferir se o empresariado é beneficiado em detrimento dos consumidores conforme ocorre a transição de um período sanitarista para um de corte mais liberal, observamos, ao contrário das expectativas, que a ANS não alterou seu rumo. Antes, seguiu e até aprofundou a toada incremental de regulação assistencial que marca sua trajetória.

A interessante constatação de que a correlação de forças políticas, expressa na ocupação dos cargos de direção da ANS, não é capaz de explicar a não inflexão liberal, ou seja, o resultado da política, reconecta-nos com a discussão precedente da literatura e nos permite expor as contribuições do trabalho. Identificamos que a perspectiva agente-principal deveria ser expandida, pois seu foco nos mecanismos de controle não daria conta da complexidade do jogo político-burocrático. De fato, a principal forma de controle das agências, que são as nomeações políticas, não explica a contento o resultado regulatório. É nesse sentido que outros fatores devem ser mobilizados para tornar a análise completa. Quem percebeu isso acuradamente, ao criticar abordagens que focalizam o controle apenas a partir de um Poder, foi Moe (1987):

Nenhuma dessas considerações sugere que o Congresso não tenha influência sobre a burocracia. O Congresso certamente é importante a esse respeito. Mas o presidente, o Judiciário, os grupos de interesse também são - e, tão importante quanto, as próprias burocracias governamentais. Precisamos de uma teoria institucional de ampla base que jogue luz sobre todos esses pontos. (Moe, 1987:477, tradução livre) 
Sem pretender conceber uma nova abordagem teórica, nosso artigo procurou levar em conta fatores institucionais e atinentes à configuração do setor, como o positive feedback, o caráter microrregulatório do arcabouço legal, o formato institucional heterogêneo das operadoras de planos de saúde e, principalmente, a autonomia burocrática. Ao serem integrados à análise, esses fatores possibilitaram-nos compreender como a ANS passou por uma transição liberal sem que a agência, de fato, mudasse o rumo de sua regulação nesse sentido. Acreditamos, portanto, que futuras análises sobre a relação entre burocracia e política no âmbito do Estado brasileiro devam atentar para a relevância de fatores institucionais e setoriais para a conformação mais ampla da influência e da produção de políticas públicas e de regulação estatal.

É importante apontar que, embora não tenhamos identificado um processo de captura na ANS, a permeabilidade entre agência e mercado é crescente. Isso se reflete não apenas na ocupação de postos de diretoria, como mostramos, mas em outros dados não apresentados por restrições de espaço, como o incremento dos vínculos do empresariado com a diretoria colegiada e com o restante do corpo de funcionários e a intensificação do fenômeno da porta giratória. Ademais, pressões externas vindas do Ministério da Saúde têm se avolumado para que a agência flexibilize suas regulações.

Paralelamente, deve-se atentar ao Judiciário, que tem tido papel decisivo no setor. Entre 2007 e 2013, o número de acórdãos sobre planos aumentou $3.379 \%$ apenas no Tribunal de Justiça de São Paulo. Esse protagonismo advém da própria especificidade da saúde suplementar, que é vista, a depender da posição ocupada pelo observador, ora como mercadoria, ora como direito social. O Judiciário, invariavelmente, interpreta o setor segundo a lógica constitucional de direitos e ignora o arcabouço regulatório definido pela lei que regulamentou o setor e pela própria agência, dando recorrentes ganhos de causa ao consumidor contra as operadoras de planos de saúde.

Frise-se, por fim, que, independentemente da regulação da ANS, as principais operadoras, como Amil, Bradesco Saúde e Qualicorp, têm um poder desproporcional e vêm auferindo crescentes benefícios no setor. Apenas para mencionar algumas medidas, destacamos, mais recentemente, a Lei $n^{\circ} 12.873 / 2013$, que concedeu benefícios estimados em $\mathrm{R} \$ 4$ bilhões por meio da redução na base de cálculo do Plano de Integração Social (PIS)/Contribuição para o Financiamento da Seguridade Social 
(Cofins), e a já citada lei que permitiu a participação do capital estrangeiro na assistência à saúde. Historicamente, o setor ainda é favorecido por renúncias fiscais, como abatimento de despesas no Imposto de Renda (IR) e isenções fiscais a entidades filantrópicas, cujo valor pode ter ultrapassado R \$ 25 bilhões em 2013 (Ocké-Reis e Gama, 2016). Não à toa, embora venha perdendo beneficiários desde 2015, o faturamento do setor segue crescente (ANS, 2018).

Conclui-se, dessa maneira, que, se por um lado não houve desvio de curso na microrregulação praticada pela ANS, em que pesem os espaços de influência angariados pelo empresariado, por outro, as conexões e o financiamento realizados pelas grandes empresas parecem ter-lhes assegurado condições de crescimento, especialmente por meio de subsídios e da permissão ampliada de fusões e aquisições via mercado externo. A custos marginalmente impostos ao setor regulado pela agência, correspondeu a possibilidade de uma forte expansão propiciada pelo Executivo central e pelo Poder Legislativo. Assim, se os fatores institucionais são predominantes na explicação do papel da ANS, o jogo político externo à agência é determinante para se compreender a configuração mais ampla da regulação na saúde suplementar, em particular as oportunidades abertas à atuação empresarial. Na esfera política mais ampla, o jogo é claramente mais desigual e favorável ao setor privado. Nesse sentido, resta saber se a influência empresarial conseguirá se estender, igualmente, à ANS e ao Judiciário.

(Recebido para publicação em 20 de setembro de 2018)

(Reapresentado em 22 de novembro de 2018)

(Aprovado para publicação em 20 de fevereiro de 2019)

\section{NOTAS}

1. Os dados relativos à primeira gestão da ANS (2000-2003) foram omitidos por restrições de espaço. De todo modo, para fins do argumento aqui apresentado, focado na mudança entre o período 2004-2009 e o posterior, não haverá prejuízo.

2. Esclarece-se que a análise de redes foi utilizada nesta pesquisa como instrumento heurístico para se deslindar as coalizões políticas no âmbito da ANS, e não como abordagem teórica para se compreender a influência exercida.

3. Os mandatos dos diretores são não coincidentes. Como dividimos os períodos conforme a gestão dos diretores-presidentes, necessariamente alguns diretores terão ocupado esse posto ao longo de duas gestões diferentes. Nesses casos, optamos por alocar o diretor na gestão em que ele exerceu a maior parte do mandato. Em relação ao ministro da Saúde, optamos por deixar os dois que ocuparam a pasta nesse período. 
4. Embora Eduardo Sales não fosse filiado ao PT no momento de sua indicação à agência, conforme mostra o Quadro 2, ele já havia sido filiado até a década de 1990, além de sua vinculação política ser com a sigla petista.

5. Embora tenhamos situado Eduardo Sales, da Difis, no grupo sanitarista, é interessante observar que Luiz Sérgio (PT-RJ), o mentor de sua indicação, cujo nome está historicamente associado ao movimento metalúrgico, recebeu R \$30 mil da operadora de planos de saúde Aliança para sua campanha a deputado federal em 2010 (TSE, 2010).

6. Não foi possível rastrear doações da Amil ao senador Renan Calheiros (PMDB-AL) nas eleições de 2010 ao Senado Federal. Detectamos, porém, que seu filho, Renan Calheiros Filho (PMDB-AL), foi o candidato a governador no Brasil que mais recebeu recursos da Amil em 2014 - R\$ 725 mil (TSE, 2010).

7. O nome de Tavares também contou com o apoio e a gestão do ex-ministro da Fazenda, Antonio Palocci, junto ao presidente Lula. À época, Palocci, que seria coordenador da campanha de Dilma Rousseff em 2010, prestava consultoria à Amil. Reforça-se, assim, a vastidão do apoio governamental que a Amil consegue angariar. Para informações sobre a consultoria de Palocci: http://www1.folha.uol.com.br/fsp/mercado/79951-conversas-diretas-destravaram-impasse.shtml

8. Nelson Barbosa, secretário-executivo do Ministério da Fazenda, e Antonio Henrique Silveira, secretário da Secretaria de Acompanhamento Econômico (SEAE), tiveram papel central nessa escolha (entrevista ao autor).

9. Nas entrevistas, ficou claro que nenhum dos atores políticos ligados ao PT no setor, como ministros e dirigentes da agência, tinha conhecimento desse fato.

10. http:/ / fusoesaquisicoes.blogspot.com.br/2016/07/fundos-carlyle-gic-e-cvc-partners. html e http://blogs.oglobo.globo.com/lauro-jardim/post/inicio-de-namoro-entre-rede-dor-e-qualicorp.html

11. http:/ / www.sinamge.com.br/index.php/2014-06-06-02-11-03/acordos-coletivos / acordos-e-diss $\%$ C3\%ADdios-2016-2017?task=download\&id=16

12. http://economia.estadao.com.br/noticias/geral,fundo-carlyle-dono-da-cvc-compra-empresa-de-planos-de-saude-qualicorp-imp-,583478

13. A essa altura, um quinto diretor havia sido nomeado na agência. Trata-se de André Longo, médico ligado ao PT indicado pelo ministro Alexandre Padilha.

14. A título de exemplo, a Amil é uma medicina de grupo, a Bradesco Saúde é uma seguradora, as Unimeds são cooperativas médicas e a Qualicorp é uma administradora de benefícios.

15. A reunião pode ser vista aqui: https://www.youtube.com/watch?v=GyYtSNf7Eik.

16. A nomeação de Abrahão à presidência da ANS foi o movimento mais radical pró-empresariado no âmbito da agência, pois ele foi presidente da Confederação Nacional de Saúde, Hospitais, Estabelecimentos e Serviços (CNS), entidade representativa dos estabelecimentos e prestadores de serviços de saúde privados, entre 2003 e 2014. A CNS foi a entidade que ajuizou uma ADIN no STF para questionar grande parte da lei do setor.

17. Por estar localizado na mesma cidade que a ANS, o Rio de Janeiro, o jornal O Globo faz um acompanhamento mais sistemático da política do setor, tornando-se o veículo mais influente. 


\section{REFERÊNCIAS BIBLIOGRÁFICAS}

ANS (Agência Nacional de Saúde Suplementar). (2018), Portal da ANS. Disponível em: $<$ http://www.ans.gov.br/>.

BAIRD, Marcello. (2016), "O lobby na regulação da publicidade de alimentos da Agência Nacional de Vigilância Sanitária (Anvisa)". Revista de Sociologia e Política, v. 24, n. 57, pp. 67-91.

BONIS, Daniel. (2016), Os limites do desenho institucional: uma investigação empírica dos mecanismos da influência presidencial sobre as agências reguladoras independentes no Governo Federal brasileiro. (Doutorado em Administração Pública e Governo), Fundação Getulio Vargas, São Paulo.

BORGATTI, Stephen P.; EVERETT, Martin G.; FREEMAN, Linton C. (2002), Ucinet for Windows: Software for Social Network Analysis. Harvard, MA, Analytic Technologies.

BRASIL. (1998), Lei no 9.656/98, de 3 de junho de 1998. Dispõe sobre os planos e seguros privados de assistência à saúde. Presidência da República, Brasília, DF.

CARRIGAN, Christopher; COGLIANESE, Cary. (2011), "The politics of regulation: from new institutionalism to New Governance". Annual Review of Political Science 2011. n. 14, pp. 107-129.

COUTO, Cláudio G.; ARANTES, Rogério B. (2006), "Constituição, governo e democracia no Brasil". Revista Brasileira de Ciências Sociais, v. 21, n. 61, pp. 41-62.

GORMLEY JR, William. (1979), "A test of the revolving door at the FCC". American Journal of Political Science, v. 23, n. 4, pp. 665-683.

LEVY, Brian; SPILLER, Pablo T. (eds.) (1996), Regulations, institutions, and commitment: comparative studies of telecommunications. Cambridge/New York, Cambridge University Press.

LIMONGI, Fernando; FIGUEIREDO, Argelina. (2001), Executivo e Legislativo na Nova Ordem Constitucional. Rio de Janeiro: Editora FGV.

LOWI, Theodore. (1972), "Four systems of policy politics, and choice". Public Administration Review, v. 32, n. 4, pp. 298-310.

MAJONE, Giandomenico. (1999), “Do Estado positivo ao Estado regulador: causas e consequências de mudanças no modo de governança". Revista do Serviço Público, v. 50, n. 1.

MARQUES, Eduardo. (2003), Redes sociais, instituições e atores políticos no governo da cidade de São Paulo. São Paulo: Annablume e Fapesp.

MATOS, João B. B. de. (2011), As transformações da regulação em saúde suplementar no contexto das crises e mudanças do papel do Estado. Tese (Doutorado em Saúde Coletiva), Universidade Federal do Rio de Janeiro, Rio de Janeiro.

MOE, Terry M. (1985), "Control and feedback in economic regulation: the case of the NLRB". The American Political Science Review, v. 79, n. 4, pp. 1094-1116.

. (1987), "An Assessment of the Positive Theory of 'Congressional Dominance'”. Legislative Studies Quarterly, v. 12, n. 4, pp. 475-520. 
OCKÉ-REIS, Carlos O.; GAMA, Filipe. (2016), Radiografia do gasto tributário em saúde 2003-2013. Brasília: IPEA.

PIERSON, Paul. (2004), Politics in time: history, institutions, and social analysis. Princeton, Princeton University Press.

PRAÇA, Sergio; FREITAS, Andrea; HOEPERS, Bruno. (2011), “Political Appointments and Coalition Management in Brazil, 2007-2010". Journal of Politics in Latin America, v. 3, n. 2, pp. 141-172.

SCHEFFER, Mario; BAHIA, Ligia. (2010), Planos e seguros de saúde: o que todos devem saber sobre a assistência médica suplementar no Brasil. São Paulo, Editora UNESP.

SILVA, Mariana. (2010), O desenho institucional em prática: uma análise da independência das agências regulatórias brasileiras (1997-2009). Brasília: Secretaria de Acompanhamento Econômico do Ministério da Fazenda.

STIGLER, George. (1975), "The Theory of Economic Regulation". In: The Citizen and the State: Essays on Regulation. Chicago: The University of Chicago Press, pp. 114-144.

TSE (Tribunal Superior Eleitoral). (2014), Portal do TSE. Disponível em: < http:/ /www. tse.jus.br/>.

(2010), Portal do TSE. Disponível em: < http://www.tse.jus.br/>.

WILSON, James. (1989), Bureaucracy: what government agencies do and why they do it. Basic Books. United States of America: Harper Collins Publishers. 


\section{RESUMO}

Da Hegemonia Sanitarista ao Predominio Liberal: Investigando os Fatores que Impediram uma Inflexão Liberal na Agência Nacional de Saúde Suplementar (ANS) (2004-2014)

Este artigo analisa a política na regulação da saúde suplementar, conduzida pela ANS. Investigamos como as disputas de poder entre sanitaristas e liberais foram transpostas para a agência a partir das nomeações políticas para os cargos de direção e como isso influenciou a regulação da ANS entre 2000 e 2014. Para caracterizar os grupos políticos nas distintas gestões, montamos redes de conexões entre políticos e diretores da ANS, examinamos o papel das operadoras no apoio a dirigentes da ANS e o perfil dos diretores. Para identificar os resultados regulatórios, analisamos as decisões-chave realizadas e o padrão de votos dos diretores. A pesquisa, ancorada em métodos mistos, fez uso de análise documental e entrevistas com 45 atores-chave do setor, que foram a base para a análise de redes. O estudo revelou que, após período de domínio sanitarista, grupos mais liberais tornaram-se majoritários na ANS. No entanto, essas mudanças na diretoria não resultaram em regulações pró-mercado. Isso é explicado pelo jogo político, bem como por fatores institucionais e setoriais, como a falta de consenso no mercado, a burocracia sanitarista da ANS, que funcionou como freio a medidas liberalizantes, e o arcabouço regulatório, que limita o poder da ANS no tocante a ações pró-mercado.

Palavras-chave: influência; lobby, burocracia; coalização governamental; ANS

\section{ABSTRACT \\ From Sanitary Hegemony to Liberal Dominance: Investigating the Factors that Prevented a Liberal Inflection at the National Health Agency - ANS (2004-2014)}

This paper analyzes the policy on supplementary health regulation conducted by the National Health Insurance Agency - ANS, in the Portuguese acronym. We investigated how power disputes between sanitarians and liberals were transposed to the agency through political appointments to management positions and how this influenced the institution's regulation between 2000 and 2014. To characterize the political groups in the different administrations, we built networks of connections between politicians and ANS directors, examined the role of health insurance companies in supporting ANS leaders, as well as the profile of directors. To identify regulatory outcomes, we analyzed key decisions made and the voting pattern of directors. The research, based on mixed methods, used document analysis and interviews with 45 key actors in the sector, which were the basis for network analysis. The study revealed that after a period of sanitary domination, the most liberal groups in the ANS became the majority. However, 
these changes in the board did not result in pro-market regulations. This is explained by the political game, as well as by institutional and sectoral factors such as the lack of consensus in the market, the sanitary bureaucracy of the ANS, which acted as a brake on liberalizing measures, and the regulatory framework, which limits the power of the ANS regarding pro-market actions.

Keywords: lobby; bureaucracy; government coalition; Brazilian National Health Agency (ANS)

\section{RÉSUMÉ}

De l'Hégémonie Sanitairiste à la Domination Libérale: Étudier les Facteurs qui ont Empêché une Inflexion Libérale dans l'ANS (2004-2014)

Ce document analyse la politique de réglementation sanitaire complémentaire menée par l'ANS. On a étudié la manière dont les rapports de force entre hygiénistes (sanitaristas) et libéraux (liberais) ont été transposés à l'organisme des nominations politiques aux postes de direction, et comment cela a influencé la réglementation de l'ANS entre 2000 et 2014. Pour caractériser les groupes politiques des différentes administrations, on a créé des réseaux de relations entre les responsables politiques et les administrateurs de l'ANS. On a examiné le rôle des opérateurs dans le soutien aux responsables de l'ANS et le profil des administrateurs. Pour identifier les résultats de la réglementation, on a analysé les principales décisions prises et la structure de vote des administrateurs. La recherche, fondée sur des méthodes mixtes, a utilisé une analyse documentaire et des entretiens avec 45 acteurs-clés du secteur, qui ont servi de base à l'analyse des réseaux. L'étude a révélé qu'après une période de régime sanitaire, des groupes plus libéraux sont devenus majoritaires au sein de l'ANS. Cependant, ces changements au sein du conseil n'ont pas abouti à une réglementation favorable au Marché. Cela s'explique par le jeu politique, ainsi que par des facteurs institutionnels et sectoriels, tels que l'absence de consensus sur le Marché, la bureaucratie sanitaire de l'ANS, qui a freiné les mesures de libéralisation, et le cadre réglementaire, qui limite le pouvoir de l'ANS en relation à mesures favorables au Marché.

Mots-clés: influence; lobby; bureaucratie; coalition gouvernementale; ANS 


\section{RESUMEN}

De la Hegemonía Sanitarista al Predominio Liberal: Investigando los Factores que Impidieron una Inflexión Liberal en la ANS (2004-2014)

Este artículo analiza la política en la regulación de la salud complementaria, conducida por la ANS. Investigamos cómo las disputas de poder entre sanitaristas y liberales fueron traspasadas para la agencia a partir de los nombramientos políticos para los cargos de dirección y cómo eso influyó la regulación de la ANS entre los años 2000 y 2014. Para caracterizar los grupos políticos en las distintas gestiones, montamos redes de conexiones entre políticos y directores de la ANS, examinamos el papel de las operadoras en el apoyo a dirigentes de la ANS y el perfil de los directores. Para identificar los resultados regulatorios, analizamos las decisiones clave realizadas y el patrón de votos de los directores. La investigación, basada en métodos mixtos, hizo uso del análisis documental y entrevistas con 45 actores clave del sector, que fueron la base para el análisis de redes. El estudio reveló que, después del periodo de dominio sanitarista, grupos más liberales se volvieron mayoritarios en la ANS. Sin embargo, esas transformaciones en la dirección no resultaron en regulaciones pro mercado. Eso es explicado por el juego político, así como por factores institucionales y sectoriales, como la falta de consenso en el mercado, la burocracia sanitarista de la ANS, que funcionó como freno de medidas liberalizadoras y la estructura regulatoria, que limita el poder de la ANS en lo que se refiere a acciones pro mercado.

Palabras clave: influencia; lobby; burocracia; coalición gubernamental; ANS 